\title{
Oblique rifting and the Late Eocene-Oligocene demise of Laurasia with inception of Molloy Ridge: Deformation of Forlandsundet Basin, Svalbard
}

\author{
Karen L. Kleinspehn $^{\mathrm{a}}{ }^{\square}$, Christian Teyssier ${ }^{\mathrm{a}}$ \\ ${ }^{\mathrm{a}}$ Department of Earth Sciences, University of Minnesota, 310 Pillsbury Drive SE, Minneapolis, MN \\ 55455, USA
}

Corresponding author. Tel.: +01 612 624 0537. E-mail address: klein004@umn.edu (K.L. Kleinspehn). Submitted to Tectonophysics, September 2015

Resubmitted to Tectonophysics, April 2016

\begin{abstract}
Final breakup of the Laurasian supercontinent occurred within a residual continental bridge that spanned Svalbard, Greenland and Arctic Canada from Late Cretaceous to Oligocene time, but the timing and precise kinematics of that breakup have remained obscure. Dextral oblique motion between Svalbard and northeastern Greenland initially generated the West Spitsbergen Fold-Thrust Belt (a transpressional orogen) but evolved into oblique rifting until the ultimate demise of the continental bridge with the Early Miocene formation of the Molloy Ridge. The Forlandsundet basin stands as a critical entity within the Svalbard continental margin whose fill captured the progressive transition between oblique convergence and divergence. The basin originated as a Late Eocene piggyback basin within the foldthrust belt during deposition of the oldest unit, the fluvio-deltaic Sarsbukta conglomerate. Structural
\end{abstract}


mapping highlights early deformation of the Sarsbukta strata expressed as (1) fractured cobbles in which fractures formed by consistent NNW-SSE stretching were injected with sandy matrix (when poorly lithified), (2) stylolites recording WSW-ENE shortening, and (3) conjugate dextral- and sinistral-normal mesoscale faults that indicate WSW-ENE shortening ( $\mathrm{P}$ axes) and NNW-SSE extension (T axes). Between 38 and $31 \mathrm{Ma}$, this episode of orogen-normal shortening with orogen-parallel extension evolved progressively into oblique divergence (NW-SE extension) recorded in the Sarsbukta strata as basin-wide strike-slip/normal faults, transtensional folds, and sub-horizontal stylolite surfaces (subvertical P axes). Thus NW-SE extension, consistent with present spreading on the Molloy Ridge, was established at least 9 m.y. before the first emergence of recognized oceanic lithosphere. Deformation occurred at upper-crustal temperatures of $\leq 104^{\circ} \mathrm{C}$ based on new vitrinite reflectance data. Transtension resulted in intrabasinal exposures of the Caledonide metamorphic basement during deposition of the second unit, the $\geq 31$ Ma fan-deltaic Sarstangen conglomerate, in the Forlandsundet graben sensu stricto. Such oblique stretching severed the continental bridge heralding ultimate oceanic spreading at the Molloy Ridge.

\section{KEYWORDS}

Tertiary Laurasian continental bridge, Svalbard; Late Eocene-Oligocene Forlandsundet basin; Oblique rifting; Transpression to transtension transition; Molloy Ridge; Hydraulically fractured cobbles

\section{Introduction}

Debate as to how continental rifts progress to sea-floor spreading as mid-ocean ridges propagate into continental lithosphere persists decades after the advent of plate-tectonic theory. The northern Gulf of California (e.g. Lizarralde et al., 2007; Umhoefer, 2011), the northern Red Sea (e.g Cochran and Karner, 
2007), and the Laptev Sea (e.g. Franke et al., 2001) exemplify rare neotectonic continental rupture from which a limited understanding of rift processes can be gleaned, but these cases entail unidirectional propagation of the spreading ridge. In contrast, Late Eocene-Oligocene rifts and continental rupture in Svalbard represent precursors to a ridge segment, the Molloy Ridge, that grew to link two ridge systems that propagated toward each other. During the final phases of opening of the North Atlantic basin but before the inception of the Molloy Ridge, a Laurasian continental bridge still connected the Greenland and Fennoscandian cratons through Svalbard (Figs. 1, 2). Late Eocene-Oligocene rifting dissected this last vestige of Mesozoic Laurasia as the Mid-Atlantic Ridge propagated northward to connect to the spreading ridge of Arctic Ocean, the Gakkel Ridge (Fig. 1c). Western Svalbard records the mode of continental break-up as the two ridges linked, finally severing the Laurasian continental bridge.

Plate reconstructions suggest that continental rupture was not accomplished by simple orthogonal extension (e.g. Døssing et al., 2013; Engen et al., 2008); rather, the region became a zone of distributed Late Cretaceous-Oligocene oblique deformation as the plate boundary propagated into the continental bridge. Notably, the modern Molloy Ridge strikes obliquely to the western margin of Svalbard but currently spreads orthogonally at ultra-slow rates $<1 \mathrm{~cm} \mathrm{yr}^{-1}$ (Fig. 2; Thiede et al., 1990; Vogt and Jung, 2004). Thus this region also exemplifies oblique rupture that evolved into orthogonal spreading. Evaluating the evolution and deformation of syn-tectonic sedimentary basins in this region reveals the kinematics, timing, and structural style under this mode of continental break-up in relation to far-field plate-tectonic boundary conditions.

Typically, rifts that do not fail are inaccessible as they lie in the offshore continental subsurface buried beneath passive-margin strata. The Late Eocene-Oligocene rift onshore on Svalbard (Fig. 1a) offers a unique exposed example of a rift segment that did not fail but eventually matured to the fullfledged, ultra-slow oceanic Molloy Ridge (Fig. 2; Vogt an Jung, 2004). The goal of this study is to use the 
accessible rift segment on Svalbard to better understand the broader zone of continental rupture that led to the demise of the continental bridge, most of which is now offshore. Structural style and strain/kinematic data typically cannot be interpreted from standard marine geophysical approaches but were readily acquired in this field study of onshore geologic structures. Thus, this rift basin on Svalbard that represents the subaerially exposed-shelf edge at the north-westernmost corner of Eurasia provides rare insight into processes of incipient oblique continental rupture through the inception of a mid-ocean ridge segment.

This study focuses specifically on the latest Eocene-Oligocene history of Forlandsundet basin on Spitsbergen, the largest island of the Svalbard archipelago, Norway (Fig. 1a) and re-evaluates the longstanding interpretation that Forlandsundet basin evolved along a simple dextral, intracontinental transform plate boundary between Svalbard and Greenland (e.g. Harland, 1969; Steel et al., 1985). Instead, Forlandsundet basin is viewed in the context of rupture of the Laurasian continental bridge, various parts of which were above sea level from Late Cretaceous time (Blythe and Kleinspehn, 1998; Dörr et al., 2013).

Much of the Forlandsundet basin is now submerged beneath Forlandsundet. This study targets the Sarsøyra peninsula on the eastern side of Forlandsundet (Fig. 1a), a coastal peneplain with sparse outcrops ( $<5 \%$ exposure). Most outcrop data are derived from coastal cliffs $\leq 3 \mathrm{~m}$ height or the bedrock walls of modern incised glacial-outwash streams, but the few more expansive exposures yield robust structural and sedimentological data. The sharp contrast in topographic relief, elevation, metamorphic grade, age, and outcrop exposure between the peneplained Paleogene basin and the adjacent mountainous metamorphic basement of the fold-thrust belt (Caledonide Hecla Hoek units) has led many previous workers to overlook the basin's structural complexity and to promote the view that the basin is a simple post-orogenic graben superimposed on the Late Cretaceous-Paleogene fold-thrust belt (e.g. 
Atkinson, 1963; Harland, 1969; 1997; Steel et al., 1985). Others recognized the basin as a more integral component of oblique deformation as the nascent plate boundary propagated into the continental bridge (Gabrielsen et al., 1992; Kleinspehn and Teyssier, 1992; von Gosen and Paech, 2001; Wojcik, 1981). Our results document the deformation and thermal evolution of the Forlandsundet basin, based on analysis of various structures and measurement of vitrinite reflectance, and indicate that basin deposition and deformation capture the transition from transpression to transtension during shearing of the continental bridge in Late Eocene-Oligocene time. The studied structures reinforce the premise that oblique stretching is mechanically advantageous, and faults whose stretching direction is oblique to the opening direction take precedence during incipient rupture (Heine and Brune, 2014).

We present a three-phase evolution of the Forlandsundet basin starting with 1) initial deposition as a piggyback basin associated with the Western Spitsbergen Fold-Thrust Belt, followed by 2) deformation of the basin, during a progressive Late Eocene transition from oblique contraction that started prior to or during lithification and culminated during dextral transtension, including evidence for folding developed during transtension, and 3) deposition of a second earliest Oligocene stratigraphic unit under transtension prior to final rupture of the continental bridge and the generation of Miocene oceanic lithosphere. By targeting the deformation of the dated fill of Forlandsundet basin, we pinpoint the latest Eocene onset of initial oblique stretching and incipient break-up of the Laurasian continental bridge associated with the initiation of the Molloy mid-ocean-ridge segment. Because deformation of the basin is dated, our results also have implications for rates of oblique rifting processes and kinematics of an evolving non-volcanic rift margin.

\section{Geologic setting, oblique rifting, and oceanic spreading}


Deformation of the continental bridge started at 88-80 Ma during Late Cretaceous opening of the Labrador Sea-Baffin Bay west of Greenland and the concurrent opening of the Norwegian-Greenland Sea east of Greenland (Døssing et al., 2013; Hosseinpour et al., 2013). At Chron 24B-25 time (57-54 Ma; Ogg, 2012), the Gakkel Ridge started spreading in the Eurasian basin north of Greenland, signifying a shift in plate motions with new poles of rotation (Døssing et al., 2013; Engen et al., 2008). Between Chrons 24 and 25, ridge propagation also became concentrated on the eastern side of Greenland while Labrador sea-floor spreading west of Greenland became highly oblique under northsouth opening (Hosseinpour et al., 2013); these plate motions drove Greenland northward into continental Arctic Canada and Svalbard (Døssing et al., 2013; Tessensohn and Piepjohn, 2000). Shortening ensued in the intervening Laurasian continental bridge from Arctic Canada through northeastern Greenland and Svalbard southward to the Barents Shelf (Berg and Grogan, 2003; Tessensohn and Piepjohn, 2000). Upper Proterozoic-Lower Paleozoic Caledonide basement of Laurasia and its Devonian-Lower Cretaceous platform cover experienced transpressive shortening to produce the contiguous Late Cretaceous-Paleogene Eurekan/Greenland/Western Spitsbergen Fold-Thrust Belt (Bergh and Grogan, 2003; Braathen et al., 1999; Tessensohn and Piepjohn, 2000), which on western Svalbard is a thick-skinned orogen extending eastward through central Spitsbergen as a thin-skinned belt (Fig. 1b; Bergh et al., 1997). The Late Eocene Forlandsundet basin was later superimposed on the thickskinned fold-thrust belt without a change in far-field plate-motion vectors and is today surrounded by the rugged glaciated peaks of the basement-involved thrust sheets on Spitsbergen and the island of Prins Karls Foreland (Figs. 1a, 1b).

Another plate reorganization and shift in poles of rotation at $\sim 33 \mathrm{Ma}$ (Chron 13) resulted in the cessation of spreading in the Labrador Sea west of Greenland, while oblique sea-floor spreading on the eastern side of Greenland persisted as the Mid-Atlantic Ridge propagated farther northward (Fig. 1c; 
Hosseinpour et al., 2013). A series of coeval extensional and/or transtensional basins along Svalbard's western margin marks the demise of the Laurasian continental bridge as the extensional component of Oligocene relative motion between Greenland and Eurasia increased (Fig. 1c). Most of those basins remain known only from offshore seismic-reflection or -refraction studies (e.g Blinova et al., 2009; Eiken and Austegard, 1987; Engen et al., 2008). Thus interpretation of rift kinematics and timing remains plagued by a paucity of direct observations.

Initiation of the Molloy Ridge segment, whose Late Eocene-Oligocene position lay immediately west of Forlandsundet basin (Fig. 2), helped split the Laurasian continental bridge leading to an ultimate linkage of the Mid-Atlantic spreading system to the Arctic Ocean's Gakkel Ridge (Fig. 1c). The continental bridge persisted at least until $22 \mathrm{Ma}$ when a narrow strip of Miocene oceanic lithosphere was initiated between continental Svalbard and the Molloy spreading ridge, lithosphere whose magnetic anomalies are partially obscured by a thick cover of young glaciogenic sediment (Engen et al., 2008). Rupture of the Laurasian continental bridge at the latitude of Forlandsundet basin certainly had been accomplished by $21 \mathrm{Ma}$ as a reversed Chron 6AA is identified in the oceanic lithosphere along the Molloy Ridge segment, but west of the spreading ridge on the Greenland side (Ehlers and Jokat, 2009; Ogg, 2012).

\section{Chronostratigraphy of Forlandsundet basin at Sarsøyra}

Traditionally, the basin fill at Sarsøyra was regarded as a single stratigraphic unit (e.g. Atkinson, 1963; Feyling-Hanssen and Ulleberg, 1984; Gabrielsen et al., 1992; Livšic, 1974, 1992; Manum, 1960; Manum and Throndsen, 1986), but our field data confirm that two unconformable Paleogene units are exposed on the eastern margin of Forlandsundet basin (Fig. 3), as defined by Dallmann (1999), with only the older unit recording a sequence of deformation. 


\subsection{Deposition of the older unit - Sarsbukta conglomerate}

The older of the two exposed units, the Sarsbukta conglomerate, consists of $>600 \mathrm{~m}$-thick gravelly meandering-channel fluvio-deltaic deposits fining upward to lithic arenites and coal-bearing overbank deposits (Figs. 4a, 4b; Rye Larsen, 1982) that display an advanced degree of lithification. The Sarsbukta conglomerate represents mature sediment with well-rounded clasts $\leq 37 \mathrm{~cm}$ diameter and lithic arenites with abundant preserved carbonaceous tree branches and leaf litter. These strata were deposited in a basin that experienced tectonism, but sufficiently slow average subsidence rates with intermittent stability that allowed repeated development of coal seams (Fig. 4b; McCabe and Parrish, 1992; Nemec, 1988). The unit yields palynomorphs, dinocysts, macroflora and marine bivalves suggesting Late Eocene (possible Middle Eocene) ages for outcrops exposed inland and on the northwest coast of Sarsøyra (Figs. 3, 5a; Dallmann, 1999; Gabrielsen et al., 1992; Livšic, 1974; Manum and Throndsen, 1986).

The basal Sarsbukta conglomerate records unroofing of the Devonian-Lower Cretaceous platform cover as it dominantly comprises sedimentary clasts along with low-grade sub-greenschist Caledonide detritus (Table 1); importantly the basal conglomerate lacks clasts of the Hecla Hoek dolomitic conglomeratic breccia now exposed adjacent to the basin suggesting a later juxtaposition of those two units. Although abundant higher-grade Hecla Hoek detritus eventually appears $\sim 50 \mathrm{~m}$ upsection (Table 1), rare paleocurrent indicators do not suggest dispersal from the nearby Hecla Hoek basement in the axis of the Western Spitsbergen Fold-Thrust Belt, but instead show widely varying azimuths typical of meandering fluvio-deltaic systems. Shortening led to unroofing of sediment sources in the Eurekan/Greenland/Western Spitsbergen Fold-Thrust Belt, thus Sarsbukta detritus could be derived from Svalbard or Greenland, given its Eocene proximity (Fig. 1b). The well-stratified, unsheared basal conglomerate contains coal seams within $1 \mathrm{~m}$ of its base suggesting an unconformable but depositional 
contact established under stability or very slow subsidence allowing the uninterrupted accumulation of peat (McCabe and Parrish, 1992; Nemec, 1988). In addition, the largest clasts do not display a systematic decrease in grain size away from the contact with the metamorphic Hecla Hoek basement. To the contrary, the largest clasts $(37 \mathrm{~cm})$ actually occur stratigraphically high in the Sarsbukta unit in the basin's interior $\sim 2 \mathrm{~km}$ away from the Hecla Hoek contact (Øyrflaket coastal locality; Fig. 5a).

These observations indicate an absence of fault-generated relief along the eastern basin margin during initial Sarsbukta deposition. Instead, the faults that currently cut the basin were superimposed on Sarsbukta fluvial-plain deposits that were much broader than the extent of modern outcrops, as suggested by Gabrielsen et al. (1992). A broader basin is also supported by the erosional remnants of Sarsbukta-age fluvium deposited on the nearby thrust sheets within the axial Western Spitsbergen Fold-Thrust Belt (Scheteligfjellet of Cepek and Krutzsch, 2001; Piepjohn et al., 2001). Thus, we propose that the Forlandsundet basin was initiated during thrusting in transpression (Kleinspehn and Teyssier, 1992), likely as a wider piggyback basin riding on Svalbard's active north to northeastvergent thrust sheets, consistent with its observed depositional contact, slow subsidence, and fluvial style dominated by fine-grained detritus.

This older conglomerate locally displays a penetrative foliation, common sinistral and dextral mesoscale faults with oblique-slip slickensides, and filled veins along fault planes as well as folds. These structures cutting the Sarsbukta conglomerate, particularly its younger strata, are the basis for the work presented here and record a Late Eocene transition from dextral transpression to transtension.

\subsection{Deposition of the younger unit-Sarstangen conglomerate}

\subsubsection{Onshore exposures of the Sarstangen conglomerate}

The much coarser Sarstangen conglomerate consists of loosely consolidated, angular alluvial- 
fan/marine fan-delta gravels devoid of slickenlined faults, folds and foliation, contrasting with the older Sarsbukta unit (Figs. 3, 4c, 4d; Dallmann, 1999; Rye Larsen, 1982). Exposures are restricted to the coast southeast of the Sarstangen spit at Balanuspynten and within the moraine of Aavatsmarkbreen at Mortensenodden (Fig. 5a). Its lack of lithification, different depositional setting, differences in clast composition (Table 1), maximum clast size of $\sim 4 \mathrm{~m}$ (Fig. 4c), and extreme clast angularity distinguish this conglomerate from the older Sarsbukta unit. The Sarstangen bimodal gravels were derived almost exclusively from the Caledonide basement (Table 1) with 0.5-4.0 m outsized clasts consisting of angular first-cycle Hecla-Hoek metamorphic debris (Fig. 4c). Clearly-visible clast imbrication suggests derivation from the east. No clasts of the older Sarsbukta siliciclastic detritus were recognizable, although rounded detrital coal clasts are present (Table 1), which could be derived from Paleozoic, Mesozoic or Sarsbukta (Eocene) coals.

Bedding in the boulder-rich gravel dips consistently $11-15^{\circ}$ to the southwest (Figs. 4d, 5a). Such dip magnitudes are comparable to the depositional slopes of modern coarse alluvial fans, particularly near the fan apex (Blair and McPherson, 1994), suggesting that bedding retains its original depositional dip. This undeformed dip, the lack of lithification, and the absence of penetrative structures indicate that Sarstangen deposition post-dated the deformation recorded by the Sarsbukta conglomerate.

A marine fauna suggests the Sarstangen alluvial fans extended basinward as coastal fan deltas. Coccolithophoridae indicate a maximum age range of latest Eocene to earliest Oligocene (NP19-NP-21; Cepek, 2001). Foraminifera species that occur $\leq 2 \mathrm{~m}$ above the base of the exposed Sarstangen conglomerate are restricted to the Lower Oligocene in the Arctic region (Eidvin et al., 1998, 2014; Feyling-Hansen and Ulleberg, 1984; Livšic, 1992; A. Nøttvedt, pers. comm. 1996). Sr-isotope ratios from those foraminifera samples indicate an age of 31 Ma (Eidvin et al., 1998, 2013) using the updated global ${ }^{87} \mathrm{Sr} /{ }^{86} \mathrm{Sr}$ curve of McArthur et al. (2012). The lack of deformation in the exposed Sarstangen 
conglomerate limits the observed deformation of the older Sarsbukta conglomerate to Late Eocene time or pre-31 Ma (or a maximum possible Middle Eocene-Early Oligocene interval of 48-31 Ma; Fig. 3), using the time scale of Ogg (2012). Given the structural relations described below, the basin had evolved to a marine rift by the time of Sarstangen deposition at $31 \mathrm{Ma}$ (basal Oligocene time).

\subsubsection{Strata previously assigned to the Sarstangen conglomerate in an offshore drill hole}

The Sarstangen conglomerate was previously defined both onshore at the outcrops described here ( 20 m-thick) and offshore in a hole drilled by Norsk Polar Navigasjon A/S in 1974 on the Sarstangen spit where $1.05 \mathrm{~km}$ of the Sarstangen unit was inferred to lie unconformably on Hecla Hoek metamorphic basement (Fig. 5b; Dallmann, 1999). However, a composite log of that drill hole suggests that stratigraphic relationships require revision.

The upper $\sim 145 \mathrm{~m}$ in the drill hole bear a Pliocene-Pleistocene calcareous, benthic foraminiferal assemblage, most commonly Cibicides lobatulus (T. Eidvin, personal communication, 2016). Other species include Elphidium excavatum, Elphidium sp. and Quinqueloculina seminulum. C. lobatulus tolerates high-energy conditions, and together with E. excavatum and Elphidium sp., indicates a shallowmarine environment. A few long-range Paleogene agglutinated foraminifera (including Bathysiphon spp. and Recurvoides spp.), echinoderm spicules, and molluscan and bryozoan fragments are also recorded (T. Eidvin, personal communication, 2016). Overall, this assemblage indicates persistent marine conditions despite Late Neogene-Quaternary uplift of Svalbard (Blythe and Kleinspehn, 1998).

Farther downhole at several intervals to a depth of $880 \mathrm{~m}$, long-range Paleogene agglutinated foraminifera recur, including Bathysiphon spp., Recurvoides spp., Reophax sp. and Cibicides sp. (T. Eidvin, personal communication, 2016). Although lithofacies interpretations are based mostly on drill cuttings, the proximal alluvial fan-fan delta facies observed in Sarstangen outcrops containing very 
large angular clasts of Hecla Hoek basement ( $\leq 4 \mathrm{~m}$ diameter) appears to be missing in the drilled subsurface. The Paleogene subsurface sequence largely comprises fine alternations of dark-grey to brown shale and light grey siltstone with occasional thin interbeds of sandstone and conglomerate. However, we speculate that a 40-m interval of conglomerate to coarse sandstone at $\sim 600-640 \mathrm{~m}$ depths with angular fragments of apparent Hecla Hoek detritus may represent the distal equivalent to the Sarstangen proximal fan facies observed onshore $\sim 5 \mathrm{~km}$ to the east. If this speculation is valid, finegrained beds with thin coal beds and stringers that occur stratigraphically higher, between 445 and 145 m, would also be Oligocene as they yielded long-range Paleogene foraminifera. Oligocene coal-bearing units are known from Renardodden basin farther south along Spitsbergen's western coast indicating that vegetation and climate were conducive to Oligocene coal generation (Fig. 1a; Dallmann, 1999).

Below $640 \mathrm{~m}$, the sequence still exhibits alternating dark silty shale and siltstone with occasional thin interbeds of conglomerate and medium-to-coarse sandstone reminiscent of the Sarsbukta conglomerate, although coal appears absent. Also below $640 \mathrm{~m}$, deformation and disruption of the stratigraphic sequence is recorded as intermittent slickensided surfaces, as observed onshore in the Sarsbukta conglomerate. Slickensides were not recognized downhole until just below the proposed distal Sarstangen conglomerate $(640 \mathrm{~m})$ and appear to demarcate four shear zones down to $1025 \mathrm{~m}$. A soft weathered horizon was noted at the top of the metamorphic basement at $1046 \mathrm{~m}$ but no shear zone was recognized.

Nowhere onshore was the Sarstangen unit observed in contact with Sarsbukta or Hecla Hoek strata, but based on its very large, angular Hecla Hoek boulders, subsurface magnetic anomalies (Krasil'ščikov et al., 1995), and a plausible distal lithofacies in the drill hole on Sarstangen spit (Fig. 5b), a fault contact is inferred between the intrabasinal Hecla Hoek exposures and the Sarstangen conglomerate (Fig. 5a). Furthermore, the elevation difference between Hecla Hoek outcrops at sea level and the top of the 
metamorphic basement at $1046 \mathrm{~m}$ depth in the drill hole suggests a fault with dip slip $\leq 1 \mathrm{~km}$ even allowing for topography on the Hecla Hoek erosional surface.

\section{Thermal history of eastern margin of Forlandsundet basin}

Coal samples were collected from both the Sarsbukta and Sarstangen units with care to distinguish between primary coal beds and stringers versus detrital coal clasts that could have been reworked from older stratigraphic units on Svalbard or Greenland. Their thermal maturity was assessed by Norsk Hydro A/S using standard commercial vitrinite-reflectance procedures in which average values $\left(\mathrm{R}_{\mathrm{O}}\right)$ were determined from 20 readings per coal sample (Personal communication, A. Nøttvedt, 1993). Results are consistent with those of Rye Larsen (1982).

Vitrinite reflectance values record two populations with distinct thermal histories. Data from primary overbank coal beds and stringers within the Sarsbukta conglomerate yield low vitrinite-reflectance values $\left(R_{0}=0.51-0.67\right)$, suggesting the maximum temperature for Sarsbukta burial and deformation is $\leq 104{ }^{\circ} \mathrm{C}$ (Barker and Pawlewicz, 1994; Paech and Koch, 2001). Vitrinite reflectance values expressed throughout the study area suggest paleotemperatures of $\sim 92^{\circ} \mathrm{C}$ (Fig. 5a). Thus the structures discussed here record deformation of the uppermost fluid-saturated crust.

In contrast to the Eocene coal beds, rounded coal clasts that were transported by Sarsbukta fluvial systems yield much higher vitrinite reflectance values $\left(\mathrm{R}_{\mathrm{O}}=1.66-2.52\right.$; Fig. 5a). This detritus was likely derived from lithified Lower Carboniferous, Lower Cretaceous (Barremian) and/or Paleocene coal units that are now restricted to the Western Spitsbergen Fold-Thrust Belt and the Central basin of Spitsbergen (Fig. 1a). Given uncertainties in the Sarsbukta dispersal directions and comparable $R_{0}$ values of Cretaceous units on Greenland (Paech, 2001) with its Eocene proximity (Fig. 1b), the coal detritus could alternatively have had a Greenland provenance. Rounded coal clasts also occur in the 
Sarstangen conglomerate with similar reflectance values of $R_{O}=1.66$ (Fig. 5a) indicating that coal detritus continued to be available to the younger Sarstangen marine fan-delta although the possibility that Sarstangen coal clasts were reworked from exhumed Sarsbukta detritus needs to be retained.

\section{Structural relations - eastern margin of Forlandsundet basin}

The structural record of Forlandsundet basin deformation includes map-scale folds and faults that tilted the sedimentary strata, as well as outcrop-scale structures including small faults, fractured clasts with systematic fracture orientations, and stylolitic surfaces from which statistical orientation data were obtained. In this section, we address first the basin-basement contact, providing new observations that modify the long-held view of the contact as a simple normal fault. We then describe structures that developed when the conglomerates were not entirely lithified, which we consider to be the earliest deformation in the basin. Crosscutting relations provide a relative chronology of subsequent deformation that captures the transition from oblique contraction to oblique extension. Finally we focus on basinscale folds and faults that are also present in the Hecla Hoek basement and likely mark the final development of oblique rifting, paving the way for the oblique drifting phase that ultimately generated the Molloy ridge segment offshore.

\subsection{Nature of basin-basement contact for the original Forlandsundet basin}

The contact between the Paleogene basin and the Caledonide Hecla Hoek basement has been considered a through-going normal fault by a number of workers (e.g. Atkinson, 1963; Braathen et al., 1999; Harland, 1969, 1997), but it is not a single continuous structure nor is it a simple normal fault

(Gabrielsen et al., 1992; Ohta et al., 1995; Bergh et al., 2000; von Gosen and Paech, 2001; Wojcik, 1981). In addition, the topographic break between the mountainous Caledonide basement and the 
peneplain underlain by Eocene strata does not mark the basin margin (Fig. 5a), as has been interpreted traditionally.

The rarely exposed basin/basement contact is depositional, although locally sheared, suggesting that the basin extended beyond its present exposure (Atkinson, 1963; Gabrielsen et al., 1992; Kleinspehn and Teyssier, 1992). The basin margin consists of segmented oblique-slip faults best exposed at the northernmost and southernmost basin margins on Sarsøyra (Fig. 5a). These map-scale faults also dissect the high-standing resistant Hecla Hoek basement, and no through-going NNW-SSE fault system, dextral or sinistral, bounds the basin.

\subsection{Early structures in the Sarsbukta conglomerate}

At several outcrops on Sarsøyra, the Sarsbukta conglomerate exhibits notable deformation in which clasts are segmented and stretched by tension fractures into which sandy matrix was injected (Figs. 6a, b). These fractures formed when the conglomerate unit was poorly lithified and/or high fluid pressures could generate natural hydraulic fractures. Highly elevated fluid pressures can be generated in basins with sediment burial of $<50 \mathrm{~m}$, thus very soon after deposition (Dugan and Germaine, 2008; Flemings et al., 2008). Such fractured clasts with injected matrix prevail in a well-exposed $100 \mathrm{~m}$-long coastal cliff on the northwestern shore of Sarsøyra. This cliff face, called the Øyrflaket coastal outcrop (ØCO; Fig. 5a), was studied in greater detail owing to its quality of exposure, higher degree of strain, and a concentration of structures and kinematic indicators. The measured structures occur within fluvial channel bodies of Sarsbukta cobble conglomerate, variably clast or matrix-supported, with bedding tilted $32^{\circ}$ to the SE (Fig. 5a); the orientation of the strata is possibly due to tilting associated with normal faults (Fig. 5a).

Finite stretching of clasts was accommodated by crack opening (tension fractures) (Figs. 6a, b) and by pervasive shear fracturing (one set or conjugate sets) commonly leading to intense clast deformation 
(Fig. 6c). Both types of fractures display a systematic orientation throughout the outcrop (Figs. $7 \mathrm{a}_{i i i}, 7 \mathrm{a}_{i v}$, 8). In general, fractures do not emanate radially from points of contact between adjacent clasts (sensu Harker, 1993; McEwen, 1981) and are not expressed in the lithic-arenite matrix. Crack opening, in which one or more fractures are filled with matrix material, indicates that deformation occurred while the sandy matrix was able to flow (Fig. 6a). Some matrix-filled cracks are quite wide at the clast edge and commonly narrow toward the center of the clast where they grade into a series of fractures in which no matrix material is discernible (Fig. 6b). In other clasts, segments are totally separated (Fig. 6a); clasts in close proximity may record extremely different degrees of stretching (Fig. 6a), suggesting that deformation was accommodated by substantial matrix mobility.

Equally common is the case of shear fractures that locally are so closely spaced that a zone of brecciation affects the whole clast. This pervasive fracturing and brecciation by shear fractures can accommodate substantial stretching of clasts (Fig. 6c). Although clasts are affected by conjugate oblique-shear fractures (both dextral and sinistral), sinistral shear fractures are more common, possibly owing to the orientation of bedding, a pre-existing clast fabric at the time of fracture development, or the location of the ØCO in a WNW-ESE sinistral shear zone. Wherever matrix-filled cracks are present, they are small in number, and the clasts lack pervasive shear fractures, suggesting that the more continuously deformed clasts, in which stretching was accommodated by pervasive shear fracturing and brecciation, did not favor crack localization. Conversely, stretching of more competent clasts was accommodated by localized fracturing and crack opening. This relation also suggests that pervasive shear fracturing and crack opening were coeval.

An evaluation of the amount of finite stretching (S) was performed in the field by measuring the total observed length (L) of 50 clasts and the sum of the length of their individual segments $\left(\mathrm{L}_{\mathrm{o}}\right)$ where the original clast shape could be restored reliably. The stretch $(\mathrm{S}=\mathrm{L} / \mathrm{Lo})$ ranges continuously up to a value 
of $\mathrm{S}=2$, which is a minimum value for bulk strain because the sandy matrix may have accommodated more stretching than the fractured clasts by "ductile" granular flow. Maximum stretching is limited to those clasts that deformed by discrete crack opening and segment separation.

Clasts are elongate in the direction 171/12, although a range of orientations exists owing in part to preexisting sedimentary fabric (Fig. $7 \mathrm{a}_{i i i}$ ). Fracture surfaces within clasts have a preferred orientation with two dominant concentrations of poles: 160/7 and 213/12 (Fig. $7 \mathrm{a}_{i v}$ ). In general, the latter is defined by sinistral shear fractures whereas the former corresponds to tension fractures normal to the clastelongation direction. These orientation data indicate that tension fractures are sub-perpendicular to the mean elongation of the clasts (Fig. $\left.7 \mathrm{a}_{i i i}\right)$.

Deformation of the conglomerate at the ØCO was accomplished not only by pervasive clast fracturing but also by development of a stylolitic foliation (dissolution) in some clasts and discrete conjugate faulting on a 1-10 m scale (Fig. 6c-f). Clast deformation is heterogeneous on the scale of the studied outcrop. Many clasts are segmented, broken, flattened or partially dissolved, whereas others are relatively well preserved, although totally undeformed clasts are rare $(<10 \%)$. The degree of clast deformation is related to clast composition and to initial shape and orientation. Clasts most affected by deformation are composed of white quartzite, green phyllitic quartzite, black phyllite, or orange dolostone. Brown and black quartzite clasts were more resistant to deformation. Sub-spherical clasts have escaped intense deformation, while elongate clasts underwent substantial stretching if oriented suitably to the strain field.

A consistently oriented stylolitic foliation developed heterogeneously on a mesoscopic scale (Fig. 6d). This foliation is defined by a saw-tooth pattern most commonly developed at the boundary between clasts, but is also found within clasts. These "ductilely" deformed clasts have aspect ratios up to 20:1 as measured normal to foliation and parallel to lineation (Fig. 6c). Such large aspect ratios contrast with the 
relatively low stretch $(\mathrm{S}=\leq 2)$ recorded by segmented clasts and highlight the prominent role of volume loss through dissolution that accompanied shear fracturing (Fig. 6c). Clasts consisting of white quartzitic pebble conglomerate, orange dolostone, and green or black phyllite exhibit the most extreme aspect ratios (Figs. 6c, d). Stylolitic surfaces trend approximately north-south and dip steeply eastward (Fig. $7 \mathrm{a}_{i v}$ ), with stylolite teeth oriented normal to stylolitic surfaces (Fig. 6d). The similarity between the orientation of stylolite surfaces and mean clast elongation direction suggests a common origin (Figs. $\left.7 \mathrm{a}_{i i i}, \mathrm{a}_{i v}\right)$.

A genetic relationship is further corroborated by meter-scale conjugate faults, up to a few meters apart, that dissect the conglomerate unit (Figs. 6e, f). The dextral-normal faults strike NE-SW and the sinistral-normal faults strike WNW-ESE (Fig. $7 \mathrm{a}_{i}, \mathrm{a}_{i i}$ ). These two populations of faults show no systematic crosscutting relationship and are thought to have developed as conjugate sets. The fault surfaces contain well-developed slickensides defined by mechanical striae and the preferred orientation of calcite crystals in slickenfibers (Fig. 6f). On the 57 measured faults, the sense of motion determined from calcite crystallization in fault steps agreed consistently with the sense of clast displacement. Total clast offset is commonly a few centimeters (Fig. 6e), up to $\sim 50 \mathrm{~cm}$. P axes (compressional/contractional) determined from these conjugate fault sets are shallowly plunging (261/33), and $\mathrm{T}$ axes (tensional/extensional) approximate the mean clast-elongation direction (163/11) as well as the mean pole to tension fractures within clasts (Fig. $\left.7 \mathrm{a}_{i i}\right)$.

All structural elements share a similar symmetry suggesting development during the same deformation event (Fig. 8a). Orientations of fracture planes within clasts, clast elongation, stylolitic surfaces, and fault slip are consistent with deformation involving bulk stretching in a direction slightly west of north $\left(340-350^{\circ}\right)$ and shortening in a direction close to east-west (Fig. 8b). The systematic obliquity of fault slip (dextral normal and sinistral normal) suggests that deformation involved a 
component of vertical shortening.

Although the ØCO is unique in its quality of exposure and relatively high strain, fractured clasts are also observed at several other Sarsbukta conglomerate localities (Fig. 9a). In particular, a series of neighboring outcrops in the southeastern part of the Sarsøyra peninsula display a number of fractured clasts, providing sufficient data for robust statistical analysis. The sub-vertical fractures in the clasts display a strong preferred orientation distributed approximately E-W, with poles to fractures again suggesting approximate $\mathrm{N}-\mathrm{S}$ stretching similar to the ØCO (Fig. $7 \mathrm{a}_{v}$ ). Like at the ØCO, the fractures were filled with unconsolidated matrix suggesting deformation occurred prior to complete lithification and developed early relative to other structures (Fig. 9a). Thus these structures as well as the coeval family of structures at the ØCO (Fig. 8) record an early cohesive basin-wide deformation of the Sarsbukta conglomerate.

\subsection{Basin-scale deformation of Sarsbukta conglomerate}

The Sarsbukta strata are affected by kilometer-scale open, upright folds whose limbs dip typically $\leq 30^{\circ}$ (Fig. 5a); based on bedding orientations, the relatively well-defined mean fold axis is oriented 306/16 (Fig. 7b $i i i)$. The basin is cut by sinistral faults striking WNW-ESE (Fig. 5a) that seem more common than the conjugate extensional oblique faults with a dextral component. Similarly trending lineaments displace linear magnetic features that likely originate in Hecla Hoek basement beneath the basin (Krasil'ščikov et al., 1995). Wherever they are observed from map- to outcrop-scale, sinistral faults are cut by NE-SW oriented normal faults that represent the latest deformation in the Forlandsundet basin.

At the outcrop scale, the Sarsbukta conglomerate is not only folded but is rich in various structures such as joints, slickensided surfaces, stylolites, and fractured clasts with injected matrix material. Outcrop-scale fold hinges were observed to trend in a general NW direction consistent with folds at 
the basin-scale (Figs. 5a, 7 $\mathrm{b}_{i i i}$ ). A stylolitic foliation is commonly observed in the coarse clastics and more rarely in the sandstone beds (Fig. 9b ). Stylolite surfaces are spaced 5-10 cm and anastomose in a slightly wavy pattern at the meter scale; stylolite teeth are typically steeply plunging (Fig. $7 b_{i i}$. The stylolitic foliation roughly follows the attitude of bedding, and where it cuts bedding, the foliation is at a shallower angle. At a locality in the southeastern part of the exposed Forlandsundet basin where stylolite foliation was measured systematically, a range of orientations from bedding-parallel to subhorizontal is observed, with anastomosing patterns and no clear crosscutting relationships (Figs. $\left.7 \mathrm{~b}_{i i}, \mathrm{~b}_{i i i}\right)$. We interpret these relations to suggest that the stylolite surfaces formed in a subhorizontal orientation during folding.

Outcrop-scale faults range from normal to strike-slip, with most faults displaying oblique slip. An analysis of 55 slickensides measured in the Eocene Sarsbukta strata shows the predominance of striae showing normal faults and normal/strike-slip faults (Fig. $7 \mathrm{~b}_{i}$ ). The $\mathrm{T}$ axes cluster in the NW-SE quadrants with a mean orientation 308/9, close to the orientation of the average fold axis (306/16; Fig. $\left.7 b_{i i i}\right)$. The $\mathrm{P}$ axes from these fault-slip data are nearly vertical, with a subsidiary maximum in a $\mathrm{SW}$ direction (Fig. $7 b_{i i}$ ). Deformation is dominated by NW extension, and the NE-SW girdle distribution of $\mathrm{P}$ axes with a subordinate cluster of subhorizontal $\mathrm{P}$ axes oriented $\mathrm{SW}$ suggest subvertical shortening as well as subhorizontal shortening (Fig. $7 b_{i i}$ ). This distribution of deformation axes, together with the normal/strike-slip nature of the measured faults and the presence of nearly horizontal stylolite surfaces and the development of gentle folds, is consistent with deformation in transtension. The gentle folds are interpreted as transtensional folds (Fossen et al., 2013) that recorded hingeparallel extension accommodated by NE-SW normal faults.

\subsection{Deformation of Hecla Hoek metamorphic basement in proximity to the basin}

The Hecla Hoek basement that bounds the Forlandsundet basin east of the studied region and 
occurs within intra-basinal fault blocks (Fig. 5a) consists of greenschist-facies phyllite, serpentinite, and Siluro-Ordovician meta-dolostone metamorphosed primarily during Paleozoic Caledonide deformation (Bergh et al., 2000; Harland, 1997; Ohta, 1988, 1994; Ohta et al., 1995; Saalmann and Thiedig, 2001, 2002). Faulting throughout the Hecla Hoek basement units is complex, reflecting multiple episodes of Paleozoic-Mesozoic deformation. However, measurements of 29 slickensides and slickenfibers on outcrop-scale basement fault planes within intra-basinal fault blocks and immediately adjacent to Forlandsundet basin show that faults are mainly normal and strike slip, with a relatively good concentration of $\mathrm{P}$ and $\mathrm{T}$ axes (Fig. 7c). The $\mathrm{P}$ axes plunge steeply and concentrate on a great circle oriented NE-SW whereas the T axes form a maximum around 309/22. These orientations are similar to those obtained from the fault-slip data from Eocene strata $\left(\mathrm{T}=308 / 9\right.$; Fig. $\left.7 \mathrm{~b}_{i i i}\right)$, suggesting that faulting of the Hecla Hoek units lying adjacent to the basin is likely of Eocene or younger age.

\subsection{Forlandsundet Graben sensu stricto - Sarstangen conglomerate}

The contact between the undeformed Sarstangen conglomerate and the older deformed units of Sarsbukta conglomerate or with Hecla Hoek basement is not exposed, but its location is inferred from the distribution of Sarstangen and Hecla Hoek outcrops as well as the positions of steep magnetic anomalies typical of serpentinites and a high-pressure Hecla Hoek metamorphic complex (Fig. 5a; Krasil'ščikov et al., 1995; Ohta et al., 1995). Imbricated Sarstangen boulders record transport westward from a local source inferred to be the basement block exposed within Forlandsundet basin (Fig. 5a). No clasts of the Sarsbukta conglomerate unit were observed in the younger Sarstangen conglomerate, suggesting that the intrabasinal basement block (Fig. 5a) may have lacked a sedimentary cover as a long-standing Paleogene structural high, or that Sarsbukta deposits were eroded prior to deposition of the Sarstangen conglomerate. Outsized Sarstangen boulders (3-4 m diameter) are consistently angular and composed of Caledonide detritus also suggesting a local source 
with steep relief, consistent with a fault scarp cutting Hoek Hoek rocks.

A fault contact between Sarstangen conglomerate and older units is inferred on the basis of these observations in the conglomerate and $>1 \mathrm{~km}$ of structural relief between Hecla Hoek metamorphic outcrops and their depth in the drill hole beneath the Sarstangen spit (Figs. 5a, b; Dallmann, 1999), but any wrench component is indeterminate. A westward dip for the fault is inferred from the distribution of surface outcrops and a prominent, southwest-dipping, polished fault plane observed in a Hecla Hoek outcrop on the coast of Sarsbukta (Fig. 5a.). These data suggest that $\leq 1 \mathrm{~km}$ fault-generated relief underlies Sarstangen spit as well as along strike north and south of the spit as a significant graben structure. Thus, the margin of the Forlandsundet graben sensu stricto does not follow the eastern basin margin, but is a younger cross-cutting structure within Forlandsundet basin; Forlandsundet graben sensu stricto lies mostly submerged beneath Forlandsundet (Fig. 5a) as one of a series of grabens offshore along Svalbard's west coast (Blinova et al., 2009; Eidvin et al., 1998; Eiken and Austegard, 1987).

Southeast of Sarstangen spit on the coast of Sarsbukta, an outcrop of Hecla Hoek brecciated dolostone displays a shallowly-dipping ( $6^{\circ}$ to $\left.\mathrm{SW}\right)$, prominently polished slip surface on which a NWSE striae orientation was measured, but no sense of slip could be determined. This fault in the Hecla Hoek basement lies along the strike of the inferred fault that delimits the Forlandsundet Graben (Fig. 5a). This relation suggests that the graben-bounding fault could be relatively low angle, but it would have to project beneath the drill hole on Sarstangen spit (Fig. 5b). This interpretation would make the graben-bounding fault a low-angle, highly oblique detachment fault. In contrast, the NE-SW oriented fault that bounds the Hecla Hoek basement block is moderately dipping to the SE and may have undergone mostly dip slip subparallel to the direction of slip on the low-angle bounding fault. Thus, these two faults that bound the mapped Hecla Hoek exposure (Fig. 5a) may be geometrically and 
kinematically linked as ramps and flats in an extensional duplex (Gibbs, 1984) and may have responded to highly oblique transtension.

\section{Discussion}

\subsection{Stratigraphic constraints for basin deformation}

The Sarsbukta conglomerate was deposited in a piggyback basin that rode on NE-verging thrust sheets as part of the transpressional Eocene West Spitsbergen Fold-Thrust Belt. Fossil assemblages record its age of <48 Ma and likely 38->31 Ma (Fig. 10). Deformation of the Upper Eocene Sarsbukta conglomerate is not reflected in the undeformed, unlithified Sarstangen conglomerate of the Forlandsundet graben sensu stricto, although the youngest Sarsbukta structures were probably contemporaneous with graben development. Chronostratigraphic data constrain opening of the Forlandsundet graben to latest Eocene-earliest Oligocene time ( $\geq 31 \mathrm{Ma}$ ). Therefore, the Sarsbukta strata recorded the transition from oblique contraction (while poorly lithified) to oblique extension in Late Eocene time as the Laurasian continental bridge was stretched obliquely and ultimately severed (Fig. 10).

\subsection{Deformation sequence}

Strata of the Sarsbukta conglomerate in the Sarsøyra region are deformed mildly in general, with the exception of the $\varnothing \mathrm{CO}$ where the rocks achieved relatively high strain involving fracturing and stretching of conglomerate clasts, formation of stylolitic foliation, and the activation of closely-spaced oblique-slip faults. The salient structural observations below serve as a basis for characterizing the deformation sequence (Fig. 10).

\subsubsection{Contraction and orogen-parallel extension}


Cobble-size clasts, wherever they are fractured in the studied region (southeastern Sarsøyra outcrops as well as the ØCO), show fractures commonly injected with matrix material, suggesting that the sediment was not well lithified during this deformation; thus we interpret this clast fracture event as the earliest deformation of the basin. The direction of stretch that fractured the clasts and opened the matrix-filled fractures (shear and tensional) resulting in clast finite elongation was consistently N-NW (Figs. 7a, 8). Locality $\varnothing \mathrm{CO}$ provides more detailed information on the nature of this deformation, including near-horizontal ENE-WSW shortening that was resolved on two sets of conjugate faults, dextral-normal and sinistral-normal, and formed the steeply dipping stylolite foliation (Fig. 8). The P and $\mathrm{T}$ axes derived from fault-slip data also indicate ENE-WSW contraction and NNW-SSE stretching, consistent with the finite elongation of stretched clasts (171/12; Fig. $\left.7 \mathrm{a}_{i i i}\right)$. The normal component of slip on faults indicates a small component of vertical shortening in addition to ENEWSW shortening (Fig. 10, transition from b1 to b2). These early structures are consistent, in terms of bulk strain, with an episode of ENE-WSW contraction accommodated by orogen-parallel extension and a transition to slight vertical shortening (Fig. 10c2). Such strain developed in poorly lithified sedimentary rocks and suggests that the transition from oblique contraction with thrust development to oblique extension with normal/strike-slip faulting signaled a fundamental change in the tectonics of the region during late Eocene time, from mountain building to orogen stretching and development of an obliquely extensional passive margin (Fig. 10b, c).

\subsubsection{Transition from contraction to transtension}

Distributed basin-scale deformation involving development of folds as well as strike-slip and normal faults overprinted the early strain recorded in poorly lithified sediment. The NW-SE folds, which were accompanied by hinge-parallel stretching and vertical shortening accommodated by normal faults and syn-folding, subhorizontal stylolite surfaces (Fig. 9b), are interpreted as 
transtensional folds (sensu Fossen et al., 2013). This NW-SE stretching direction imparted a dextral component to oblique motion relative to the axis of the Western Spitsbergen Fold-Thrust Belt (Fig. 10a). In oblique divergence, the elongation direction, expressed by $\mathrm{T}$ axes and stretched fold hinges, rotates toward the direction of oblique divergence (Teyssier and Tikoff, 1999). All these structures record a significant kinematic shift to bulk NW-SE elongation under transtension (Fig. 10b, c2). This direction is close to the inferred relative-motion vector, based on sea-floor magnetic anomalies (Engen et al., 2008), for opening of the oblique rift between Svalbard and Greenland and signals the demise of the Laurasian continental bridge (Fig. 10a).

\subsubsection{Oblique rifting}

The last deformation developed structural relief and intrabasinal exposure of Caledonide Hecla Hoek basement by faulting that also accommodated Sarstangen conglomerate deposition (Fig. 10c3). After Sarstangen deposition, the Forlandsundet graben sensu stricto continued to receive sediment, but the locus of deformation migrated farther out on the continental margin where continental rupture occurred and sea-floor spreading localized along the Molloy ridge (Fig. 10a).

Importantly, our structural data from the older Sarsbukta conglomerate demarcate a Late Eocene change in deformation from oblique convergence to oblique rifting at a time when reorganization of plate-motion vectors, as recorded by sea-floor magnetic anomalies, is not recognized (Engen et al., 2008). Our data from the Sarsbukta conglomerate show that the northwesterly spreading direction (Fig. 7), one that is ongoing across the Molloy Ridge segment (Fig. 2) and south of Svalbard (307 across Knipovich Ridge; Curewitz et al., 2010), was already established in Late Eocene time before breakup of the continental bridge. A lag time exists between initial oblique continental stretching and production of any anomaly-bearing oceanic lithosphere; for Forlandsundet basin, that estimated lag time ranges from 33-31 Ma until 22-21 Ma, or approximately 9-12 m.y. of oblique stretching prior to 
production of oceanic lithosphere along the Molloy Ridge (Fig. 2).

Two transform fault zones delimit the extent of the modern Molloy Ridge, one of which projects into the study area (Fig. 2). These transform zones are similar in orientation to the sinistral faults that dominate early Forlandsundet basin faulting (Fig. 5a), raising the question about the role these faults played in the ultimate break-up geometry along this continental margin. According to our study, the direction of motion between Greenland and Svalbard rotated from convergence to divergence during an episode of orogen-parallel stretching accommodated by a set of dextral and sinistral faults oriented SWNE and WNW-ESE, respectively. As the vector of oblique divergence rotated progressively westerly from the strike of the orogen (NW-SE extension documented in this study), the WNW-ESE faults were in a suitable orientation to become the transform faults that bounded the NE-SW-striking "protoMolloy" spreading center. This style of break-up departs from other oblique rifts like the Gulf of California, where segments of the San Andreas transform fault are re-used as transform faults for incipient spreading centers (Umhoefer, 2011). A higher angle of oblique divergence between Greenland and Svalbard may account for this difference. The sinistral fault system that developed initially at a high angle to the dextral transpressive margin provided a suitable orientation for transform motion during break-up, allowing the development of the Molloy Ridge perpendicular to the direction of spreading, but with a trend that differs profoundly from the obliquely spreading ridges to its north and south (Fig. 10a).

\section{Conclusions}

The eastern side of Forlandsundet basin records the progressive Late Eocene-Oligocene transition from oblique convergence to oblique divergence in Svalbard during the demise of the last Laurasian continental bridge. Initial deposition (Sarsbukta conglomerate) began in a broader piggyback basin within the active West Spitsbergen Fold-Thrust Belt, possibly after $38 \mathrm{Ma}$, whereas structures 
controlling the second depositional phase (Sarstangen conglomerate) cut across and segmented the piggyback basin as the Forlandsundet graben sensu stricto opened before or at $31 \mathrm{Ma}$.

Structures associated with both stratigraphic units embody deformation internal to the continental bridge prior to rupture. Early structures in Sarsbukta strata include (1) fractured cobbles in which fractures formed by consistent NNW-SSE stretching were injected with sandy matrix (when poorly lithified), (2) stylolites recording WSW-ENE shortening, and (3) conjugate dextral and sinistral mesoscale faults, with a minor component of normal motion, that indicate WSW-ENE shortening (P axes) and NNW-SSE extension (T axes). This episode of orogen-normal shortening with orogen-parallel extension evolved progressively into oblique divergence (NW-SE direction of extension) that was recorded in the Sarsbukta strata in the form of basin-wide strike-slip/normal faults, transtensional folds, and sub-horizontal stylolite surfaces (subvertical $\mathrm{P}$ axes). Vitrinite reflectance records Sarsbukta deformation entirely at upper-crustal temperatures of $\leq 104{ }^{\circ} \mathrm{C}$. Transtension resulted in intrabasinal exposures of the Caledonide (Hecla Hoek) metamorphic basement. This NW-SE direction of oblique divergence was established as early as Late Eocene time (between 38 and $\geq 31 \mathrm{Ma}$ ) and likely generated oblique rifts such as the Forlandsundet graben sensu stricto in which the Sarstangen unit of the Forlandsundet basin was deposited. Transtensional deformation also favored activation of large-scale WNW-ESE sinistral faults, as seen in Forlandsundet basin, faults that likely guided oceanic spreading at the Molloy ridge and the eventual orientation of its transform faults.

\section{Acknowledgements}

Norsk Hydro A/S kindly provided vitrinite reflectance analyses. Many thanks go to Tor Eidvin of the Norwegian Petroleum Directorate for identification of fossil assemblages in the Sarstangen drill hole and Dag Bering for release of the composite well log. This research was supported by National Science 
Foundation grant DPP-9022689, Statoil, and a University of Minnesota Grant-in-Aid of Research. Special thanks are due to Will Maze for the valuable assistance and stimulating discussions during reconnaissance field work.

\section{References}

Allmendinger, R. W., Cardozo, N. C., Fisher, D., 2012. Structural Geology Algorithms: Vectors \& Tensors: Cambridge, England, Cambridge University Press, 289 pp.

Atkinson, D.J., 1963. The Tertiary rocks of Spitsbergen. American Association of Petroleum Geologists Bulletin, 47: 302-323.

Barker, C.E., Pawlewicz, M.J., 1994. Calculation of vitrinite reflectance from thermal histories and peak temperatures. In: Mukhopadhyay, P.K., Dow, W.G. (Eds.), Vitrinite Reflectance as a Maturity Parameter Applications and Limitations. ACS Symposium Series 570. American Chemical Society, Washington, DC, 216-229.

Bergh, S.G., Grogan, P., 2003. Tertiary structure of the Sorkapp-Hornsund Region, South Spitsbergen, and implications for the offshore southern extension of the fold-thrust Belt. Norwegian Journal of Geology, 83(1): 43-60.

Bergh, S.G., Braathen, A., Andresen, A., 1997. Interaction of basement-involved and thin-skinned tectonism in the Tertiary fold-thrust belt of central Spitsbergen, Svalbard. American Association of Petroleum Geologists Bulletin, 81(4): 637-661.

Bergh, S.G., Maher, H.D., Jr., Braathen, A., 2000. Tertiary divergent thrust directions from partitioned transpression, Brøggerhalvøya, Spitsbergen. Norsk Geologisk Tidsskrift, 80(2): 63-81, doi: $10.1080 / 002919600750042573$. 
Blair, T., McPherson, J., 1994. Alluvial fans and their natural distinction from rivers based on morphology, hydraulic processes, sedimentary processes and facies assemblages. Journal Sedimentary Petrology, A64: 450-459.

Blinova, M., Thorsen, R., Mjelde, R. Faleide, J.I., 2009. Structure and evolution of the Bellsund Graben between Forlandsundet and Bellsund (Spitsbergen) based on marine seismic data. Norwegian Journal of Geology, 89: 215-228.

Blythe, A.E., Kleinspehn, K.L., 1998. Tectonically versus climatically driven Cenozoic exhumation of the Eurasian plate margin, Svalbard: Fission-track analyses. Tectonics, 17(4): 621-639, doi:10.1029/98TC01890.

Braathen, A., Bergh, S.G., Maher, H.D., 1999. Application of a critical wedge taper model to the Tertiary transpressional fold-thrust belt on Spitsbergen, Svalbard. Geological Society of America Bulletin, 111(10): 1468-1485, doi:10.1130/0016-7606(1999)111<1468:AOACWT>2.3.CO;2.

Cepek, P., 2001. Paleogene calcareous nannofossils from the Firkanten and Sarsbukta formations on Spitsbergen. Geologisches Jahrbuch, B 91: 535-547.

Cepek, P., Krutzsch, W., 2001. Conflicting interpretations of the Tertiary biostratigraphy of Spitsbergen and new palynological results. In: F. Tessensohn (Editor), Intra-Continental Fold Belts CASE 1: West Spitsbergen. Geologisches Jahrbuch, B 91, Bundesanstalt für Geowissenschaften und Rohstoffe, Hannover, pp. 551-599.

Cochran, J.R., Karner, G.D., 2007. Constraints on the deformation and rupturing of continental lithosphere of the Red Sea: The transition from rifting to drifting. In: Karner, G.D., Manatschal, G., Pinheiro, L. M. (Ed.), Imaging, Mapping and Modelling Continental Lithosphere Extension and Breakup. Geological Society, London, Special Publications 282: 265-289, doi: $\underline{10.1144 / \mathrm{SP} 282.13 .}$ 
Curewitz, D., Okino, K., Asada, M., Baranov, B., Guseva, E., Tamaki, K., 2010. Structural analysis of fault populations along the oblique, ultra-slow spreading Knipovich Ridge, North Atlantic Ocean, $74^{\circ} 30^{\prime} \mathrm{N}-77^{\circ} 50^{\prime}$ N. Journal Structural Geology, 32(6): 727-740, doi:10.1016/j.jsg.2009.08.011.

Dallmann, W.K. (Ed.), 1999. Lithostratigraphic Lexicon of Svalbard Review and Recommendations for Nomenclature Use. Norsk Polarinstitutt, Tromsø, 318 pp.

Dörr, N., Clift, P.D., Lisker, F., Spiegel, C., 2013. Why is Svalbard an island? Evidence for two-stage uplift, magmatic underplating, and mantle thermal anomalies. Tectonics, 32: 1-14, doi:10.1002/tect.20039.

Døssing, A., Hopper, J.R., Olesen, A.V., Rasmussen, T.M., Halpenny, J., 2013. New aero-gravity results from the Arctic: Linking the latest Cretaceous-early Cenozoic plate kinematics of the North Atlantic and Arctic Ocean. Geochemistry, Geophysics, Geosystems, 14(10): 4044-4065, doi: 10.1002/ggge.20253.

Dugan, B., Germaine, J.T., 2008. Near-seafloor overpressure in the deepwater Mississippi Canyon, northern Gulf of Mexico. Geophysical Research Letters: L02304, doi:10.1029/2007GL032275.

Ehlers, B.-M., Jokat, W., 2009. Subsidence and crustal roughness of ultra-slow spreading ridges in the northern North Atlantic and the Arctic Ocean. Geophysical Journal International 177 (2), $451-$ 462, doi: 10.1111/j.1365-246X.2009.04078.x.

Eidvin, T., Goll, R.M., Grogan, P., Smelror, M., Ulleberg, K., 1998. The Pleistocene to Middle Eocene stratigraphy and geological evolution of the western Barents Sea continental margin at well site 7316/5-1 (Bjørnoya west area). Norsk Geologisk Tidsskrift, 78(2): 99-123.

Eidvin, T., Riis, F., Rasmussen, E.S., Rundberg, Y., 2013. Investigation of Oligocene to Lower Pliocene deposits in the Nordic area. Norwegian Petroleum Directorate Bulletin No. 10. Available online 
at: http://www.npd.no/engelsk/cwi/pbl/NPD_papers/Hyperlink-NPD-Bulletin-10.pdf (Accessed $12 / 12 / 15) /$

Eidvin, T., Riis, F., Rasmussen, E.S., 2014. Oligocene to Lower Pliocene deposits of the Norwegian continental shelf, Norwegian Sea, Svalbard, Denmark and their relation to the uplift of Fennoscandia: A synthesis. Marine and Petroleum Geology, 56: 184-221, doi: 10.1016/j.marpetgeo.2014.04.006.

Eiken, O., Austegard, A., 1987. The Tertiary orogenic belt of West Spitsbergen: Seismic expressions of the offshore sedimentary basins. Norsk Geologisk Tidsskrift, 67: 383-394.

Engen, Ø., Faleide, J.I., Dyreng, T.K., 2008. Opening of the Fram Strait gateway: A review of plate tectonic constraints. Tectonophysics 450 (1-4), 51-69, doi:10.1016/j.tecto.2008.01.002.

Feyling-Hanssen, R.W., Ulleberg, K., 1984. A Tertiary-Quaternary section at Sarsbukta, Spitsbergen, Svalbard, and its foraminifera. Polar Research, 2(1): 77-106.

Flemings, P.B., Long, H., Dugan, B., Germaine, J., John, C.M., Behrmann, J.H., Sawyer. D., 2008. Erratum to "Pore pressure penetrometers document high overpressure near the seafloor where multiple submarine landslides have occurred on the continental slope, offshore Louisiana, Gulf of Mexico" [Earth and Planetary Science Letters 269/3-4 (2008) 309-32]. Earth and Planetary Science Letters, 274: 269-283, doi: 10.1016/eps1.2007.12.005.

Fossen, H., Teyssier, C., Whitney, D.L., 2013. Transtensional folding. Journal of Structural Geology 56: 89-102, http://dx.doi.org/10.1016/j.jsg.2013.09.004.

Franke, D., Hinz, K., Oncken, O., 2001. The Laptev Sea Rift. Marine and Petroleum Geology, 18(10): 1083 -1127, doi:10.1016/S0264-8172(01)00041-1.

Gabrielsen, R.H. Kløvjan, O. S., Haugsbø, H., Midbøe, P. S., Nøttvedt, A., Rasmussen, E., Skott, P. H., 1992. A structural outline of Forlandsundet Graben, Prins Karls Forland, Svalbard. Norsk 
Geologisk Tidsskrift, 72: 105-120.

Gibbs, A. D., 1984. Structural evolution of extensional basin margins, Journal of the Geological Society, London, 141: 609-620.

Harker, R.I., 1993. Fracture patterns in clasts of diamicitites (? Tillites). Journal Geol. Society London, 150: 251-254, doi: 10.1144/gsjgs.150.2.0251.

Harland, W.B., 1969. Contribution of Spitsbergen to understanding of tectonic evolution of North Atlantic Region. American Association Petroleum Geologists Memoir, pp. 817-851.

Harland, W.B., 1997 (Ed.). The Geology of Svalbard. Geological Society of London Memoir 17: 521 pp.

Heine C., Brune S., 2014, Oblique rifting of the Equatorial Atlantic: Why there is no Saharan Atlantic Ocean. Geology 42: 211-214, doi:10.1130/G35082.1.

Holtzman, B. K. 1999. Two Geologic Examples of a Rigid Inclusion Deforming in a Ductile Matrix: Fractured Pebbles and Chromite Pods. Unpublished M.S. thesis, 146 pp., University of Minnesota.

Hosseinpour, M., Müller, R.D., Williams, S.E., Whittaker, J.M., 2013. Full-fit reconstruction of the Labrador Sea and Baffin Bay. Solid Earth, 4: 461-479. doi:10.5194/se-4-461-2013.

Kleinspehn, K.L., Teyssier, C., 1992. Tectonics of the Paleogene Forlandsundet Basin, Spitsbergen: A preliminary report. Norsk Geologisk Tidsskrift, 72: 93-104.

Krasil'ščikov, A.A., Kubansky, A.P., Ohta, Y., 1995. Surface magnetic anomaly study on the eastern part of the Forlandsundet Graben. Polar Research, 14(1): 55-68.

Livšic, J.J., 1974. Paleogene deposits and platform structure of Svalbard. Norsk Polarinstitutt Skrifter, 159, Oslo, $50 \mathrm{pp}$.

Livšic, J.J., 1992. Tectonic history of Tertiary sedimentation of Svalbard. Norsk Geologisk Tidsskrift, 
72: $121-127$.

Lizarralde, D., Axen, G.J., Brown, H.E., Fletcher, J.M., González-Fernández, A., Harding, A.J., Holbrook, W.S., Kent, G.M., Paramo, P., Sutherland, F., Umhoefer, P.J., 2007. Variation in styles of rifting in the Gulf of California. Nature, 448: 466-469, doi:10.1038/nature06035.

Manum, S., 1960. Some dinoflagellates and hystrichosphaerids from the Lower Tertiary of Spitsbergen. Nytt Magasin for Botanikk, 8: 17-25.

Manum, S.B., Throndsen, T., 1986. Age of Tertiary Formations on Spitsbergen. Polar Research, 4(2): $103-131$.

Marrett, R. A., Allmendinger, R. W., 1990. Kinematic analysis of fault-slip data. Journal of Structural Geology, 12: 973-986, doi:10.1016/0191-8141(90)90093-E.

McArthur, J.M., Howarth, R.J., Shields, G.A., 2012. Chapter 7 - Strontium Isotope Stratigraphy. In: Gradstein, F.M., Ogg, J.G., Schmitz, M.D., Ogg, G.M. (Eds.), The Geologic Time Scale 2012. Elsevier, Boston, pp. 127-144, http://dx.doi.org/10.1016/B978-0-444-59425-9.00007-X.

McCabe, P.J., Parrish, J.T., 1992. Controls on the distribution and quality of Cretaceous coals. In: McCabe, P.J., Parrish, J. T (Eds.), Controls on the Distribution and Quality of Cretaceous Coals. Geological Society of America Special Paper 267, pp. 1-5, doi: 10.1130/SPE267-p1.

McEwen, T.J., 1981. Brittle deformation in pitted pebble conglomerates. J. Structural Geology, 3(1): 2537, doi: 10.1016/0191-814(81)90054-7.

Nemec, W., 1988. Coal correlations and intrabasinal subsidence: A new analytical perspective. In: Kleinspehn, K.L., Paola, C.P. (Eds.), New Perspectives in Basin Analysis. Frontiers in Sedimentary Geology Springer, New York, pp. 161-188, doi:10.1007/978-1-4612-3788-4_8.

Ogg, J.G., 2012. Chapter 5-Geomagnetic Polarity Time Scale. In: Gradstein, F.M., Ogg, J.G., Schmitz, M.D., Ogg, G.M. (Eds.), The Geologic Time Scale 2012. Elsevier, Boston, pp. 85-113, doi: 


\subsection{6/B978-0-444-59425-9.00005-6.}

Ohta, Y., 1988. Structures of Carboniferous strata at Trygghamna and along the SE margin of the Forlandsundet Graben. Norsk Polarinstitutt Rapportserie, 46: 25-28.

Ohta, Y., 1994. Caledonian and Precambrian history in Svalbard: A Review, and an implication of escape tectonics. Tectonophysics 231: 183-194, doi:10.1016/0040-1951(94)90129-5.

Ohta, Y., Krasil'ščikov, A.A., Lepvrier, C., Tebenkov, A.M., 1995. Northern continuation of Caledonian high-pressure metamorphic rocks in central-western Spitsbergen. Polar Research, 14(3): 303315.

Paech, H.J., 2001. The Tertiary and Cretaceous of Spitsbergen and North Greenland: Its alpine signature. Polarforschung, 69: 107-115, hdl:10013/epic.29833.d001.

Paech, H.J., Koch, J., 2001. Coalification in post-Caledonian sediments on Spitsbergen. In: F. Tessensohn (Ed.), Intra-Continental Fold Belts CASE 1: West Spitsbergen. Geologisches Jahrbuch, Reihe B, Heft 91. Bundesanstalt für Geowissenschaften und Rohstoffe, Hannover, pp. 507-530.

Piepjohn, K., Saalmann, K., Thiedig, F., Paech, H.J., 2001. The relationship of the Ny Ålesund Tertiary to the West Spitsbergen fold-and-thrust belt. In: F. Tessensohn (Ed.), Intra-Continental Fold Belts CASE 1: West Spitsbergen. Geologisches Jahrbuch, Reihe B, Heft 91. Bundesanstalt für Geowissenschaften und Rohstoffe, Hannover, pp. 447-470.

Rye Larsen, M., 1982. Forlandsundet Graben (Paleogen), Svalbard's Vestmargin, Sedimentasjon og Tektonisk Utvikling av et Basseng ved en Transform Plategrense. Unpublished Candidatus Mag thesis, 380 pp., Universitetet i Bergen.

Saalmann, K., Thiedig, F., 2001. Tertiary West Spitsbergen fold and thrust belt on Brøggerhalvøya, Svalbard: Structural evolution and kinematics. Tectonics, 20(6): 976-998, 
doi:10.1029/2001TC900016.

Saalmann, K., Thiedig, F., 2002. Thrust tectonics on Brøggerhalvøya and their relationship to the Tertiary West Spitsbergen Fold-and-Thrust Belt. Geological Magazine, 139(1): 47-72, doi:10.1017/S0016756801006069.

Steel, R., Gjelberg, J., Helland-Hansen, W., Kleinspehn, K. L., Nøttvedt, A., Rye-Larsen, M., 1985. The Tertiary strike-slip basins and orogenic belt of Spitsbergen. In: Biddle, K.T., Christie-Blick, N. (Eds.), Strike-slip Deformation, Basin Formation, and Sedimentation. Society of Economic Paleontologist and Mineralogists Special Publication 37: 339-359.

Tessensohn, F., Piepjohn, K., 2000. Eocene compressive deformation in Arctic Canada, north Greenland and Svalbard and its plate tectonic causes. Polarforschung, 68: 121-124, hdl:10013/epic.29798.d001.

Teyssier, C., Tikoff, B., 1999. Fabric stability in oblique convergence and divergence. Journal Structural Geology, 21: 969-974, doi:10.1016/S0191-8141(99)00067-X.

Thiede, J., Pfirman, S.L., Schenke, H.W., Reil, W., 1990. Bathymetry of Molloy Deep: Fram Strait between Svalbard and Greenland. Marine Geophysical Researches, 12(3): 197-214, doi: 10.1007/BF02266713.

Umhoefer, P.J., 2011. Why did the Southern Gulf of Californai rupture so rapidly? — Oblique divergence across hot, weak lithosphere along a tectonically active margin. GSA Today, 21(11), DOI: $10.1130 /$ G133A.1.

Vogt, P.R., Jung, W.Y., 2004. The Terceira Rift as hyper-slow, hotspot-dominated oblique spreading axis: A comparison with other slow-spreading plate boundaries. Earth and Planetary Science Letters, 218(1-2): 77-90, doi:10.1016/S0012-821X(03)00627-7.

von Gosen, W., Paech, H.J., 2001. Structures in the Tertiary sediments of the Forlandsundet Graben. In: 
F. Tessensohn (Ed.), Intra-Continental Fold Belts CASE 1: West Spitsbergen. Geologisches Jahrbuch, Reihe B, Heft 91. Bundesanstalt für Geowissenschaften und Rohstoffe, Hannover, pp. 475-502.

Wojcik, C., 1981. Geological observations in the eastern part of the Forlandsundet Graben between Dahlbreen and Engelsbukta, Spitsbergen. Studia Geological Polonica, 73: 25-38.

Fig. 1. a) Study locality in northwestern Spitsbergen on the eastern margin of the Forlandsundet basin, a basin superimposed on the Western Spitsbergen Fold-Thrust Belt (thrust faults with teeth) in Paleogene time. PKF is Prins Karls Forland; modern landmasses are white; Paleogene basins are stippled; inset map shows location of 1a in Svalbard. 1b) Reconstruction of mid-Eocene ( 48 Ma) Laurasian continental bridge between Svalbard and Greenland showing transpressional development of the Eurekan/Greenland/Western Spitsbergen Fold-Thrust Belt (diagonal stripes) from Arctic Canada southeastward to the Barents Shelf of Norway. 1c) Reconstruction of Late Eocene/Early Oligocene ( $\sim 34 \mathrm{Ma})$ Laurasian continental bridge between Svalbard and Greenland. FB denotes Forlandsundet Basin. Figs. b, c) Modern landmasses are stippled and continental shelves are white. Horizontally striped pattern denotes oceanic lithosphere with incipient oceanic lithosphere inferred along the Molloy mid-ocean ridge segment west of Forlandsundet basin (FB). Figs. b, c) Maps after Blythe and Kleinspehn (1998), Døssing et al. (2013), Engen et al. (2008) and Tessensohn and Piepjophn (2000). 
Fig. 2. Restoration of the Molloy mid-ocean ridge segment to its schematic pre-spreading position to emphasize the relation between oblique stretching recorded in Forlandsundet basin (FB) and the nascent spreading plate boundary west of Svalbard. Dashed rectangle outlines the study area. Dating the onset of dextral-oblique stretching (38- $\geq 31 \mathrm{Ma})$ in the study area onshore on Svalbard (dashed rectangle) constrains the inception of the Molloy Ridge segment to latest Eocene time.

Fig. 3. The Paleogene stratigraphy of the eastern margin of Forlandsundet basin in relation to the tectonic sequence presented in this paper. A two-phase Paleogene depositional history started with the Middle(?) to Upper Eocene coal-bearing, meandering fluvio-marine deltaic Sarsbukta conglomerate exposed over broad basin areas. Early deformation of this now-lithified unit occurred prior to lithification during a Late Eocene onset of transtensional continental stretching. The earliest Oligocene Sarstangen conglomerate, exposed best in the western part of the study area (Fig. 5a), represents undeformed, unlithified alluvial-fan/marine fan-deltaic strata that were superimposed on the broader, older Forlandsundet basin. Marine Plio-Pleistocene units are known from an offshore hole drilled beneath Sarstangen spit (Fig. 5b). Q is Quaternary deposits.

Fig. 4. Field photos of the older Sarsbukta conglomerate and younger Sarstangen conglomerate at Sarsøyra. a) Typical Sarsbukta conglomeratic meandering-channel body (on left outlined with light dashed line) with thinly bedded, finer-grained overbank deposits (right), including coal beds and stringers, behind the 1-m measuring stick. b) Sampling coal stringers in the Sarsbukta unit for vitrinite-reflectance analysis in a NE-dipping fold limb. c) Note the eastward-dipping imbrication (right-dipping) of $>1.2 \mathrm{~m}$ angular, outsized clast in the Sarstangen conglomerate on which the 19-cm long notebook is standing. d) Typical Sarstangen conglomerate showing texture, clast sizes and angularity of clasts in the apical alluvial-fan facies. Diffuse bedding dips consistently $11-15^{\circ}$ toward the southwest (left). 
Fig. 5. Geological map of the eastern margin of Forlandsundet basin at Sarsøyra. a) Darker colors distingu locations of actual outcrops in the coastal plain from lighter areas lacking outcrop exposure. Yellow denotes areas underlain by the Upper Eocene Sarsbukta conglomerate and orange is the Lower Oligocene Sarstangen conlgomerate; red is Caledonide metamorphic Hecla Hoek basement. Blue hand points to Øyrflaket coastal outcrop (ØCO) where a high-strain zone in the Sarsbukta conglomerate was studied in detail (Figs. 6, 7a, 8). Grey contours, expressed mostly in the mountainous Hecla Hoek areas, demarcate 50-m intervals, whereas grey light dashed lines in the basinal peneplain denote modern streams. White denotes modern glaciers; cobble pattern indicates Holocene moraines. Map is based on field observations (black) combined with grey structures inferred from the subsurface magnetic-anomaly data of Krasil'ščikov et al. (1995). Black dots denote vitrinite-reflectance data with numbers in rectangles representing values from detrital rounded coal clasts within the Sarsbukta and Sarstangen conglomerates that are distinguished from numbers in ellipses representing $\mathrm{R}_{\mathrm{o}}$ values from coal beds in the Eocene Sarsbukta conglomerate that record maximum burial and deformation temperatures $\leq 104{ }^{\circ} \mathrm{C}$. b) Map showing location of a hole drilled on Sarstangen spit by Norsk Polar Navigasjon A/S in 1974 in relation to the field study area on Sarsøyra peninsula shown in a).

Fig. 6. Deformation of the Sarsbukta conglomerate at Øyrflaket coastal outcrop; location shown in Fig. 5a and structural data in Figs. 7a, 8. a) Conglomerate clasts with sandy lithic-arenite matrix injected between the clast segments suggesting fracturing prior to lithification. Arrow demarcates separation of clast segments to show extreme degree of stretching. b) Segments of a quartzite cobble are separated by fractures filled with pebbly matrix suggesting fracturing prior to lithification. The lowest cobble illustrates shear fracturing. Orientations of fractures in cobbles 
are systematic recording elongation in a north-south direction. c) Pervasive fracturing and brecciation by shear fractures in white quartzitic pebble conglomerate and orange dolostone clasts that accommodated substantial stretching of "ductilely" deformed clasts. Their very large aspect ratios highlight the prominent role of volume loss through dissolution that accompanied shear fracturing. Arrow denotes the long axis of a single highly stretched quartzitic clast. d) Photo looking down on a subhorizontal surface showing approximately north-south trend of stylolitic surfaces between deformed clasts that dip steeply eastward. Width of notebook shown is $10 \mathrm{~cm}$. e) Steeply dipping conjugate mesoscale faults expressed on a subhorizontal outcrop surface. Dextral-normal faults strike northeast-southwest and sinistral-normal faults strike westnorthwest-east-southeast. Notebook is $19 \mathrm{~cm}$ long. f) Fault plane displaying well-developed slickensides defined by mechanical striae with a preferred orientation of calcite crystals in slickenfibers that record sinistral shear with minor component of normal slip. Pencil tip at lower left for scale.

Fig. 7. Lower-hemisphere equal-area projections synthesizing kinematic indicators for a, b) the Eocene Sarsbukta conglomerate, and c) the Caledonide metamorphic Hecla Hoek basement within the Forlandsundet basin and along the basin's eastern margin (Fig. 5a). Heavy arrows summarize the interpreted kinematics; $n$ is the number of field measurements. Black stars in contoured fault-plane solutions denote mean orientations for the compressional (P) axes and tensile (T) axes determined from slickenlined mesoscale fault planes. In (a) fault-plane solutions and other structural data from the high-strain zone in the Sarsbukta conglomerate at the Øyrflaket coastal outcrop (Fig. 6). Location shown in Fig. 5a. $\left.a_{i i i}\right)$ Black star denotes mean elongation direction determined from segmented, fractured clasts. $\mathrm{a}_{i v}$ ) Black star also denotes mean pole to stylolites. $\mathrm{a}_{i i i}$ ) Fractured clasts from outcops in the SE part of the basin that contain similarly 
oriented clasts fractures compared to $\mathrm{a}_{i v . .}$ In (b) fault-plane solutions, stylolite orientations (ii) and mean fold axis (open star) from bedding orientations (iii) from throughout the Paleogene basin. Data were analyzed using Allmendinger et al. (2012) and Marrett and Allmendinger (1999).

Fig. 8. a) Graphic summary of structural data (Fig. 7a) for the Sarsbukta conglomerate in the highstrain zone at the Øyrflaket coastal outcrop (ØCO; Location shown on Fig. 5a). Injection of sandy matrix between stretched-clast segments and the consistency of symmetry among structural elements suggest development under similar bulk strain when the sandy matrix was unlithified. From Holtzman (1999). b) Summarized orientations of fracture planes within clasts, clast elongation, stylolitic surfaces, and fault slip are consistent with deformation involving bulk stretching in a direction slightly west of north and shortening in a direction close to east-west.

Fig. 9. Outcrop-scale deformation of the Upper Eocene Sarsbukta conglomerate in the southeastern part of the study area. a) Segmented clast was stretched by tension fractures into which sandy, pebbly matrix was injected. Pencil is $17 \mathrm{~cm}$ long. b) Sub-horizontal, anastomosing stylolitic foliation developed in gravelly sandstone, shown both at a distance and close-up, highlighting stylolitic teeth.

Fig. 10. Sequence summarizing a) regional Svalbard-Greenland tectonics in the context of changing plate motions during temporally constrained deposition and the Late Eocene-earliest Oligocene deformation sequence from the eastern side of Forlandsundet Basin (FB) at Sarsøyra, Svalbard in relation to b) evolving strain components, and c) a basin deposition and deformation history based on structural relations (c1-3) with temporal control illustrated in (c4). 
Table 1. Conglomerate clast compositions in percent for the Sarsbukta and Sarstangen conglomerates at Sarsøyra. The stratigraphically-high Øyrflaket coastal outcrop is demarcated on the geologic map (Fig. 5a). Rounded clasts are denoted by (r) whereas (a) indicates pronounced angularity. 


\begin{tabular}{|c|c|c|c|c|c|c|c|}
\hline & $\begin{array}{c}\text { Hecla } \\
\text { Hoek } \\
\text { quartzite }\end{array}$ & $\begin{array}{c}\text { Hecla Hoek } \\
\text { schist/ } \\
\text { phyllite }\end{array}$ & $\begin{array}{c}\text { Other } \\
\text { Hecla Hoek } \\
\text { meta-rock } \\
\text { types }\end{array}$ & $\begin{array}{l}\text { Vein } \\
\text { quartz }\end{array}$ & $\begin{array}{l}\text { Vol- } \\
\text { canic }\end{array}$ & $\begin{array}{c}\text { Sedi- } \\
\text { mentary }\end{array}$ & Coal \\
\hline $\begin{array}{c}\text { Sarstangen } \\
\text { conglomerate }\end{array}$ & $23(a, r)$ & $22(a, r)$ & $2(a, r)$ & $36(r)$ & $2(r)$ & $13(a, r)$ & $2(a, r)$ \\
\hline $\begin{array}{l}\text { Sarsbukta cgl } \\
\text { at Øyrflaket - } \\
\text { NW Sarsøyra }\end{array}$ & $34(r)$ & $23(r)$ & $11(r)$ & 10 & $3(r)$ & $6(r)$ & $13(r)$ \\
\hline $\begin{array}{l}\text { Sarsbukta } \\
\text { cgl above } \\
\text { base - SE } \\
\text { Sarsøyra }\end{array}$ & $67(r)$ & $6(r)$ & -- & $7(a, r)$ & $4(r)$ & $14(r)$ & $2(a, r)$ \\
\hline $\begin{array}{c}\text { Basal } \\
\text { Sarsbukta } \\
\text { cgl SE } \\
\text { Sarsøyra }\end{array}$ & -- & $21(r)$ & $22(r)$ & 2 (a) & -- & $55(r)$ & -- \\
\hline
\end{tabular}




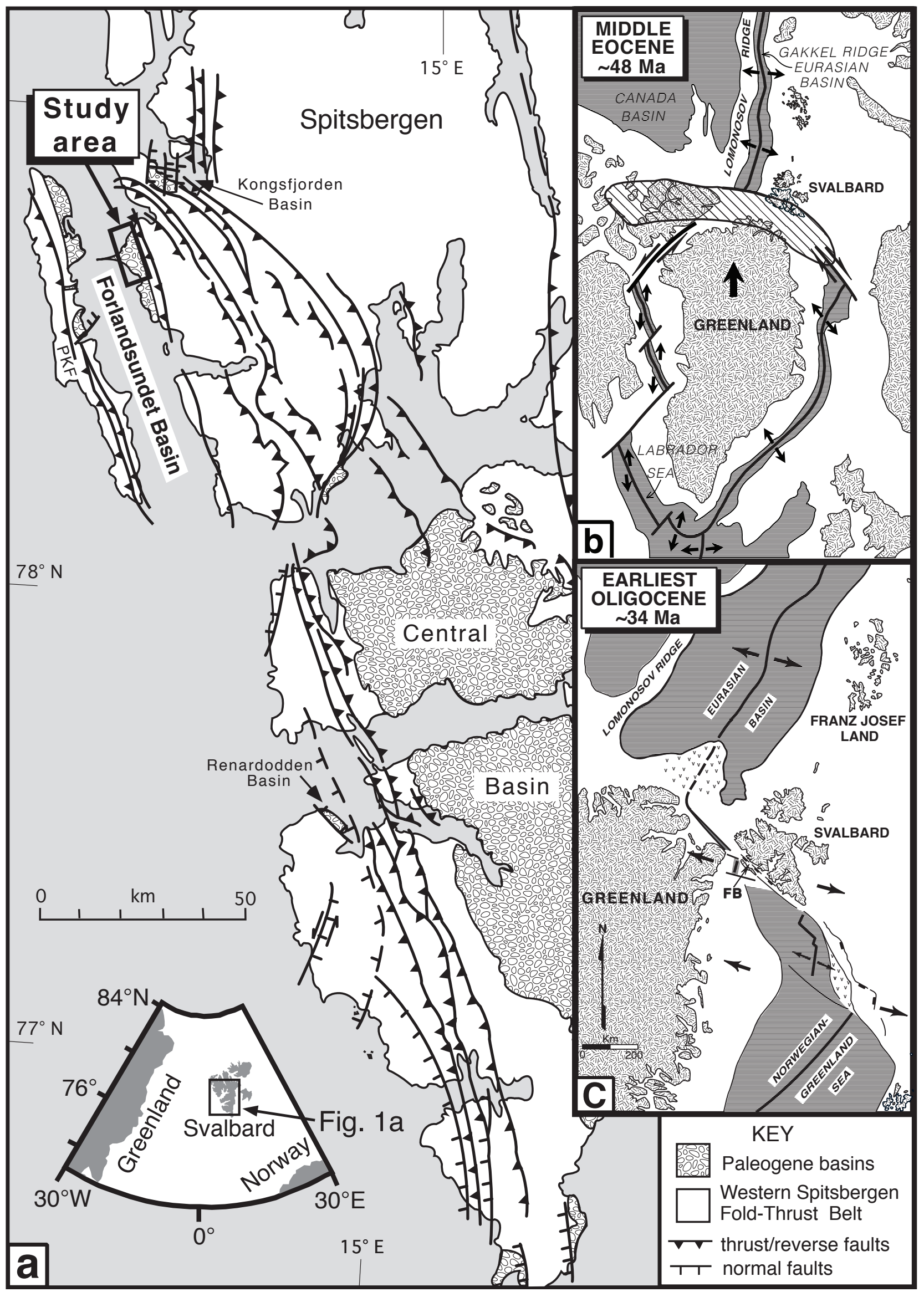

Fig. 1 - Kleinspehn and Teyssier 


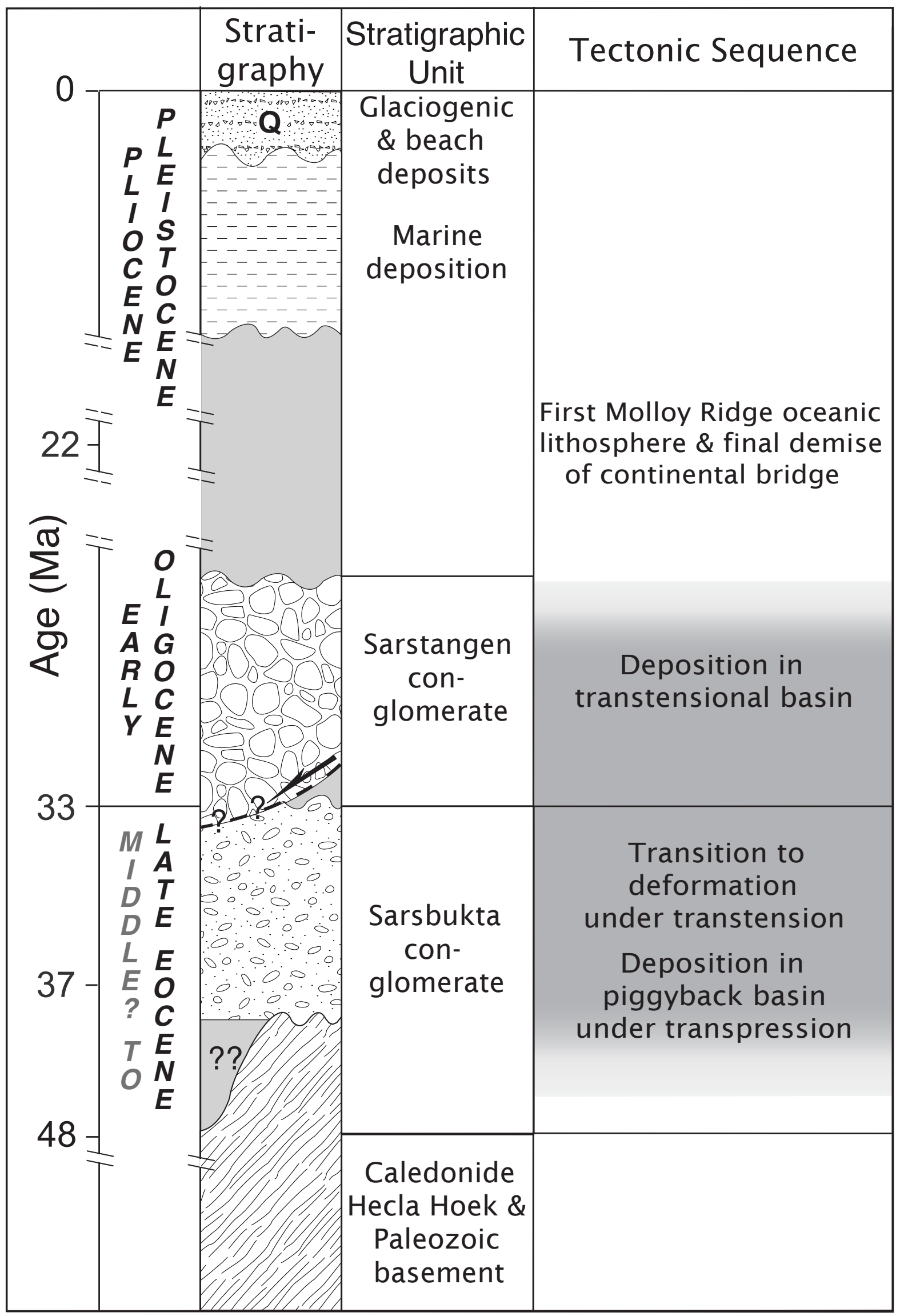

Fig. 3 - Kleinspehn and Teyssier 


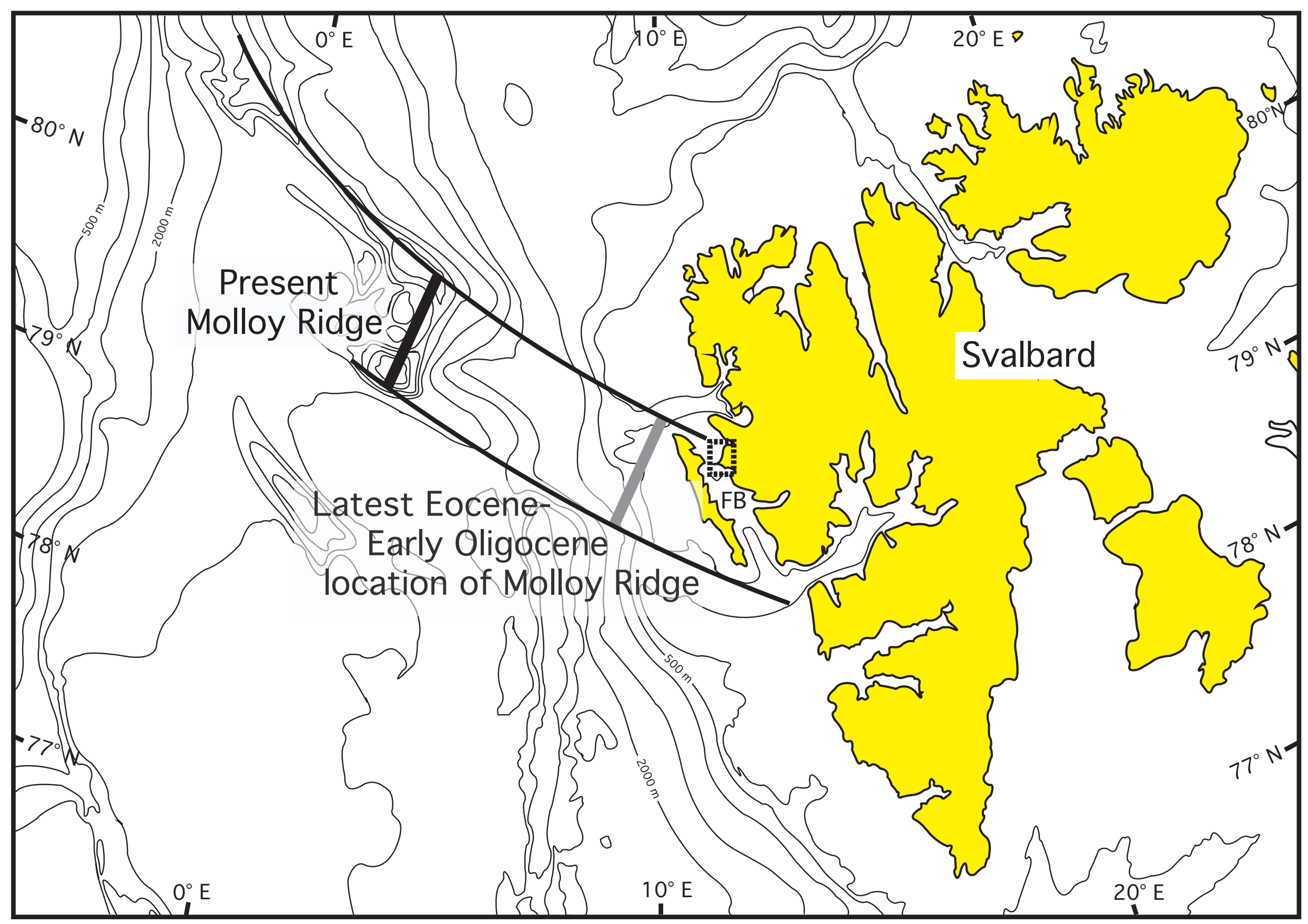

Fig. 2 - Kleinspehn and Teyssier 


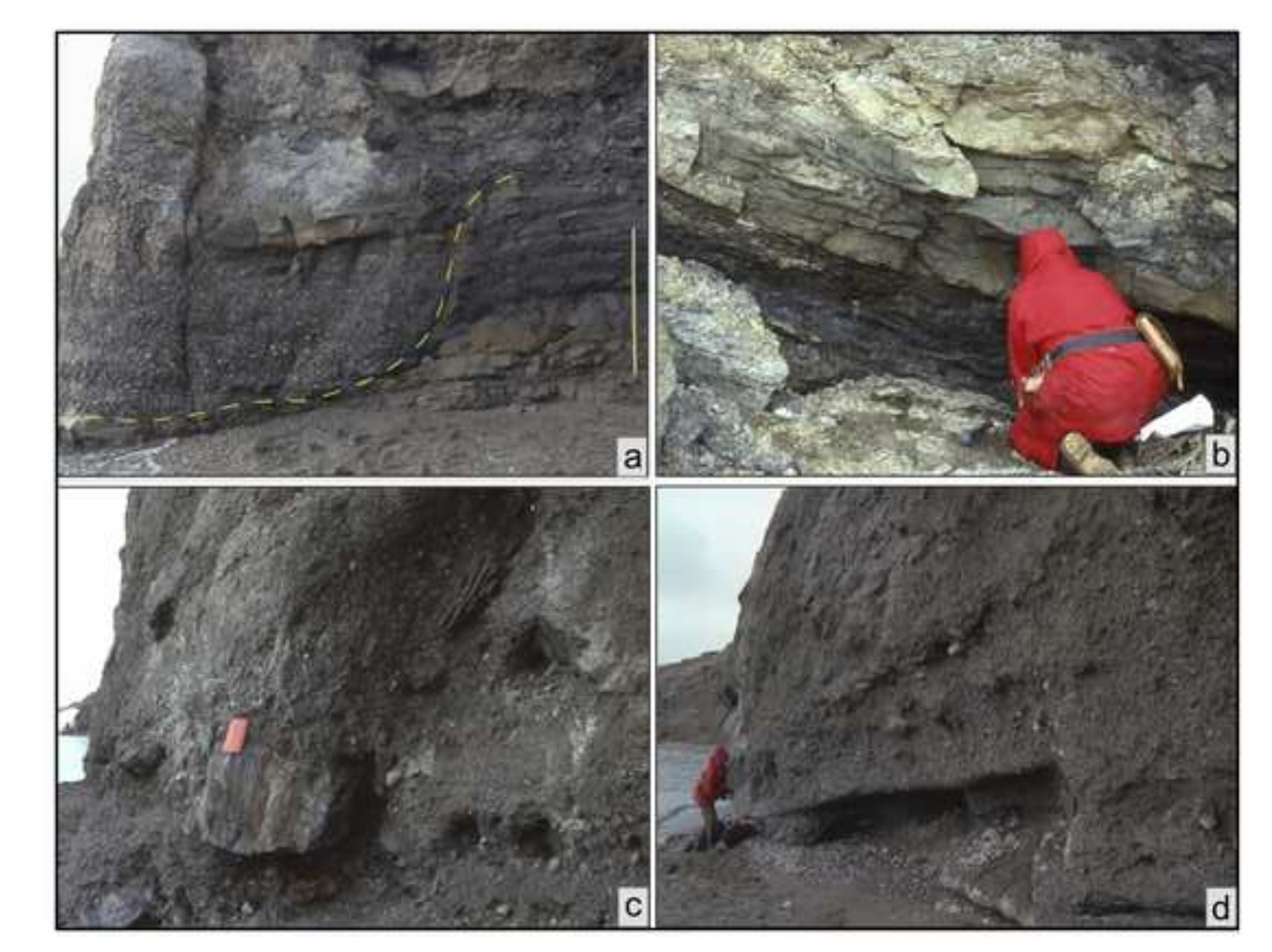

Fig. 4-Kleinspehn and Teyssier

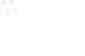

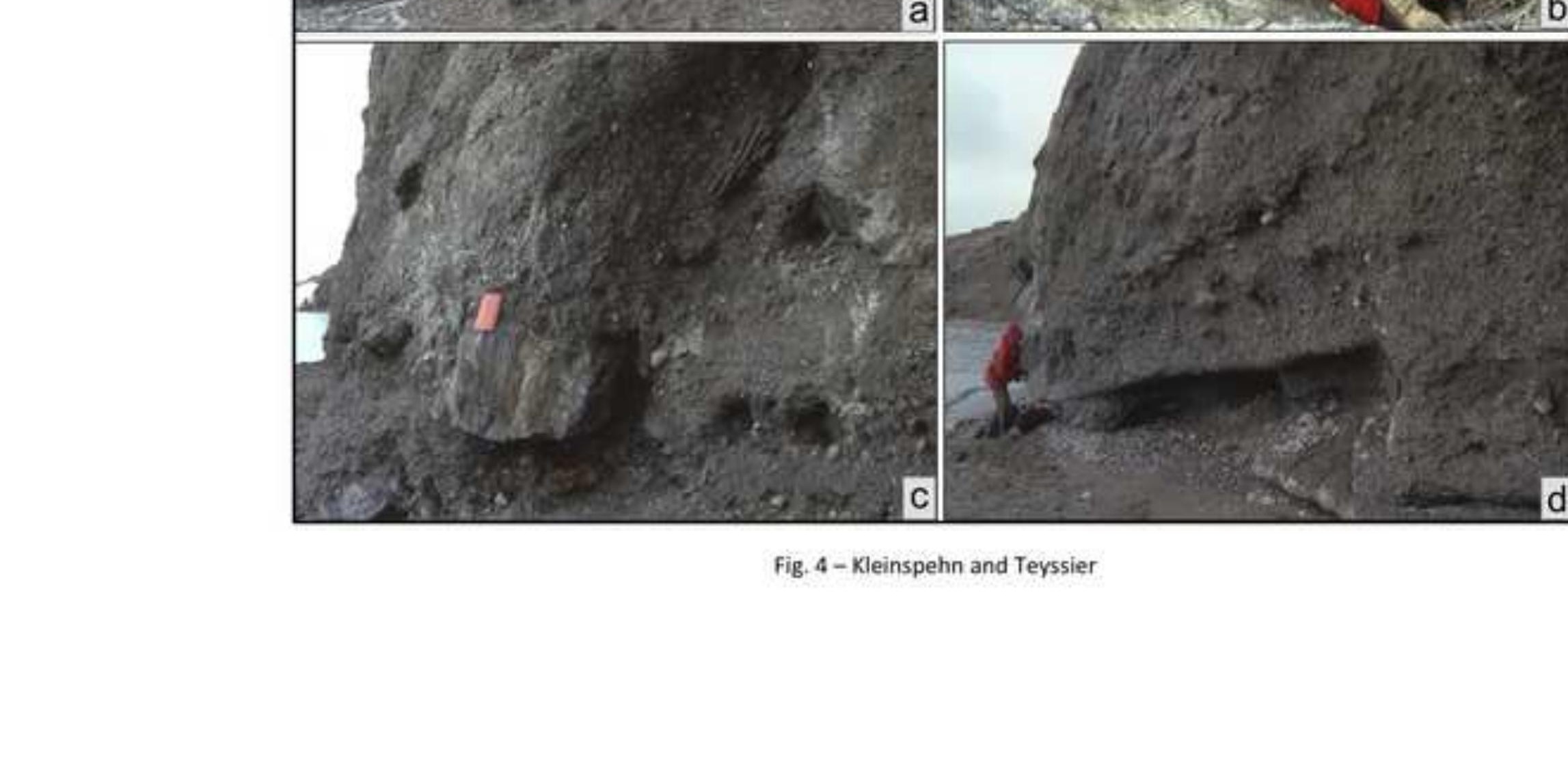

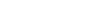

.
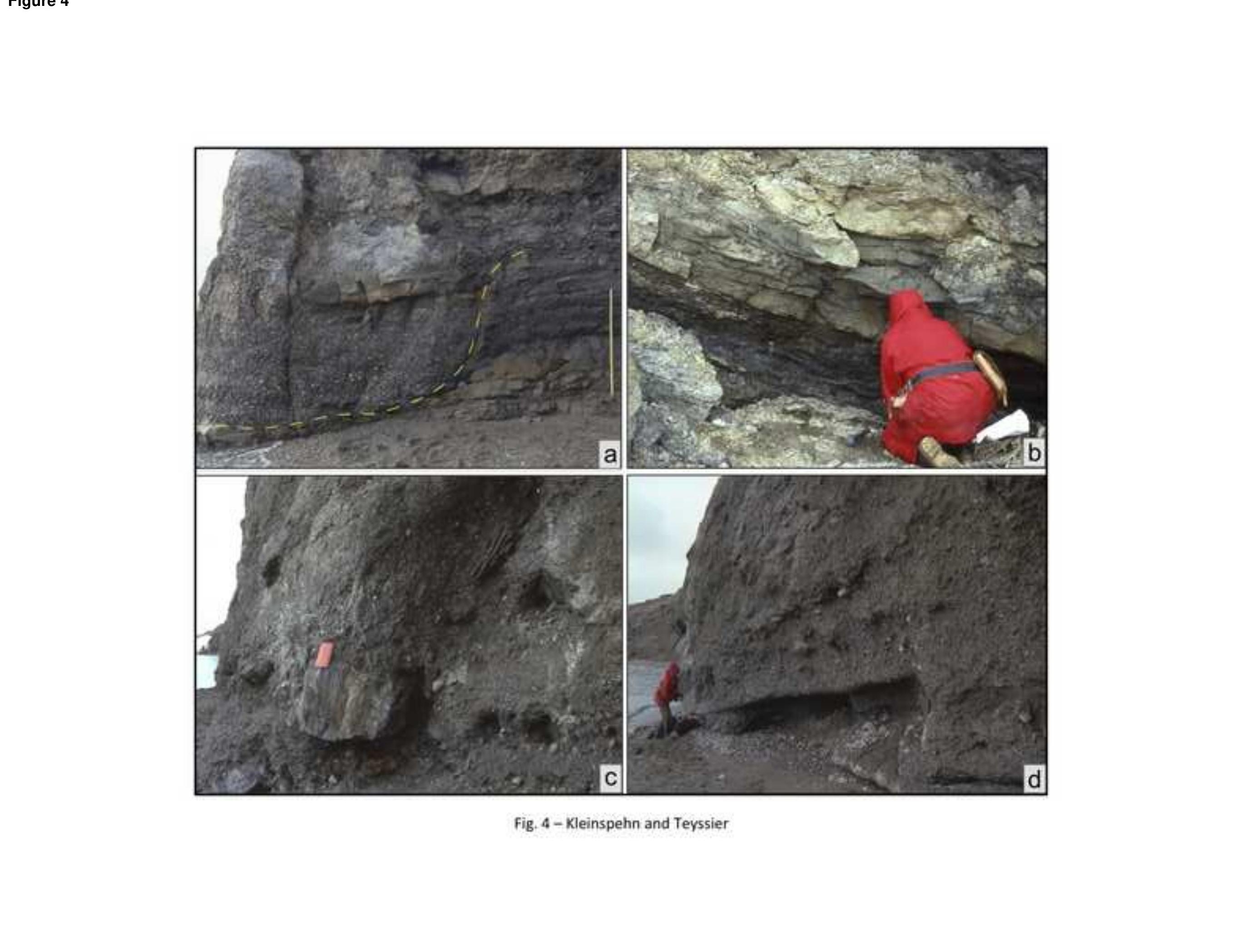


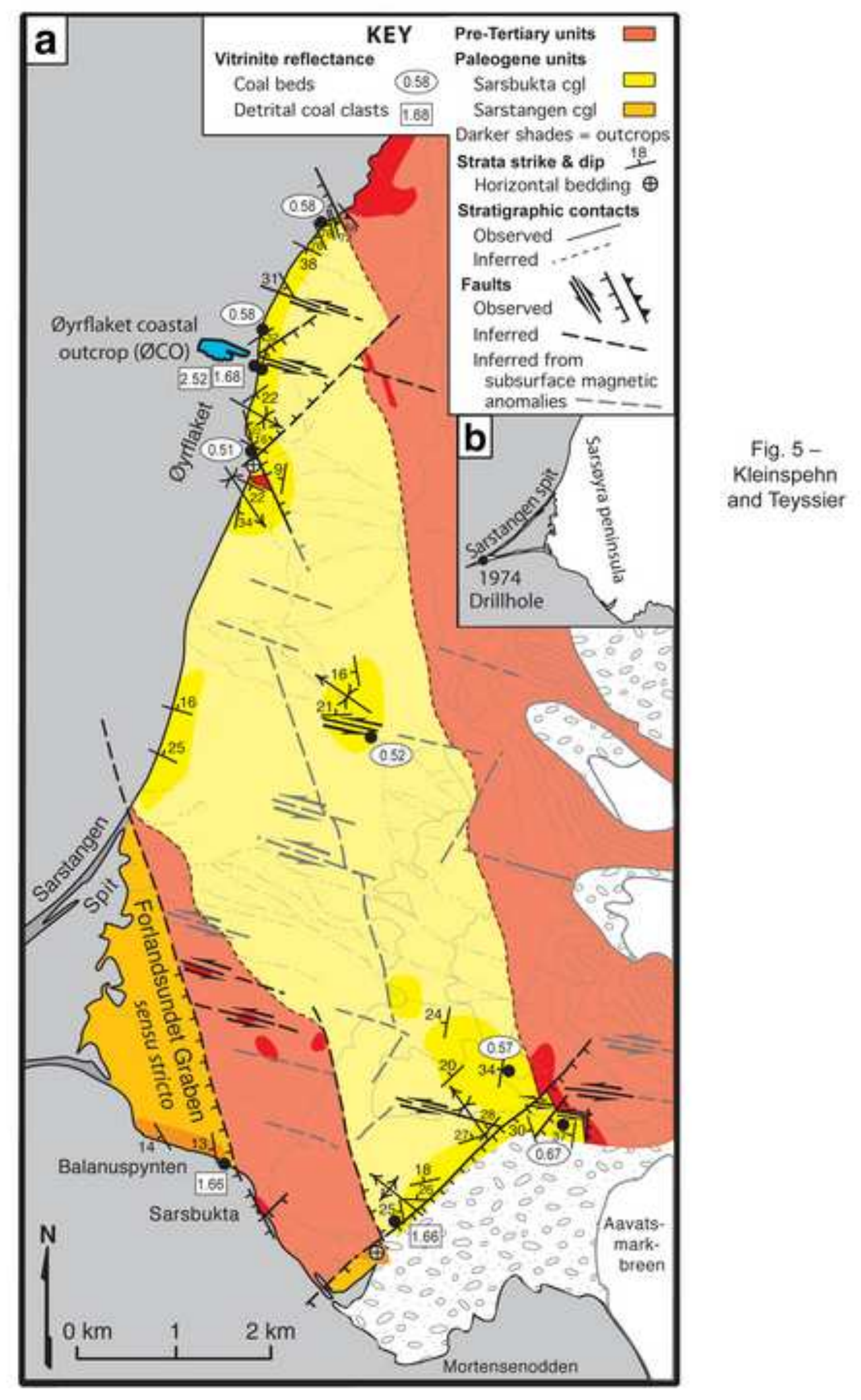

Fig. 5 Kleinspehn and Teyssier 

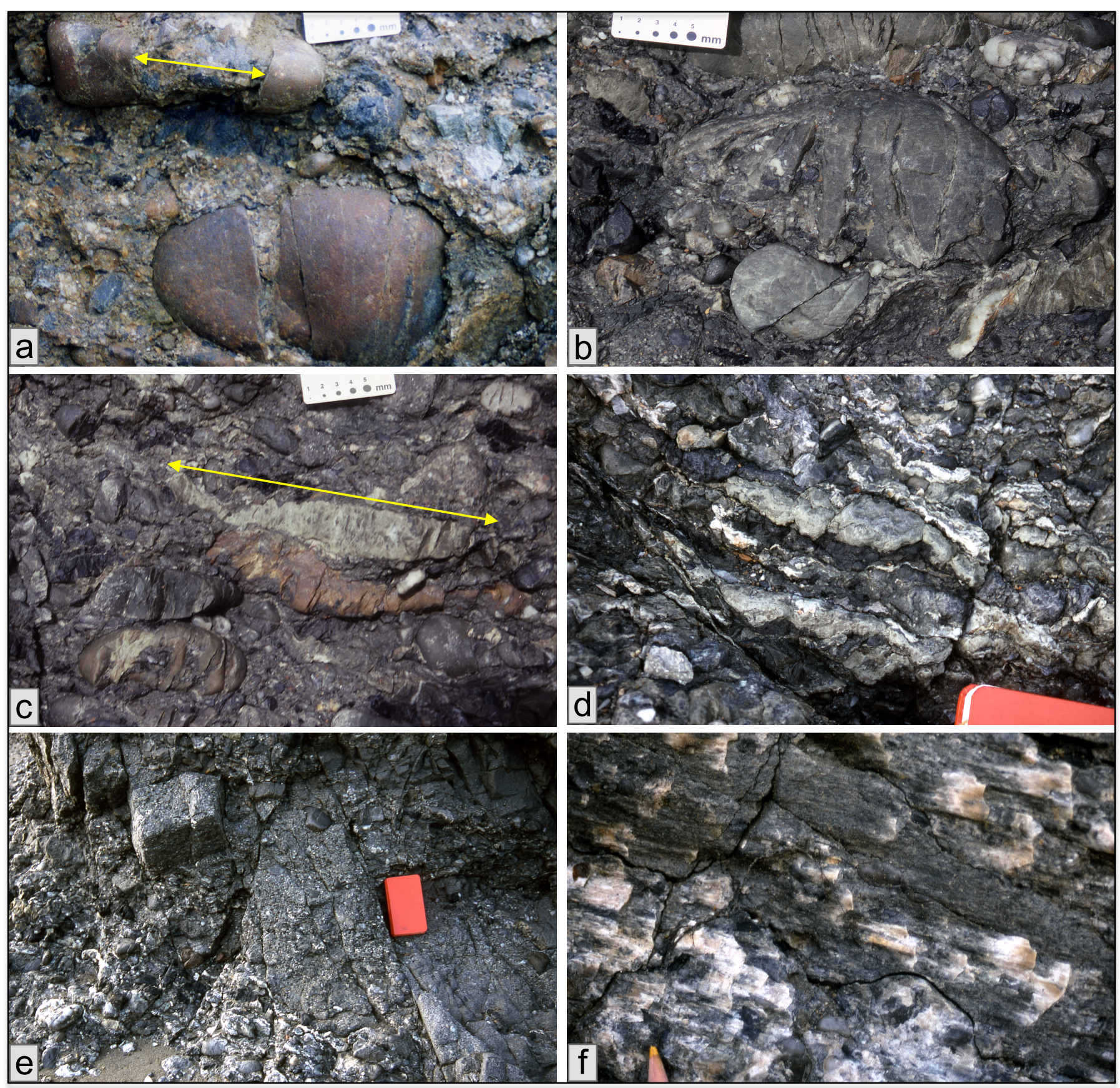

Fig. $6-$

Kleinspehn and Teyssier

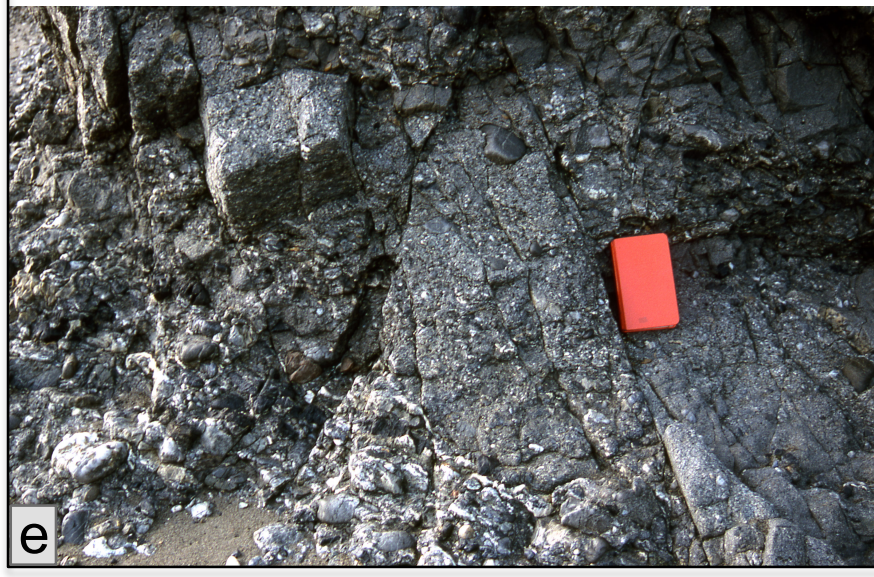



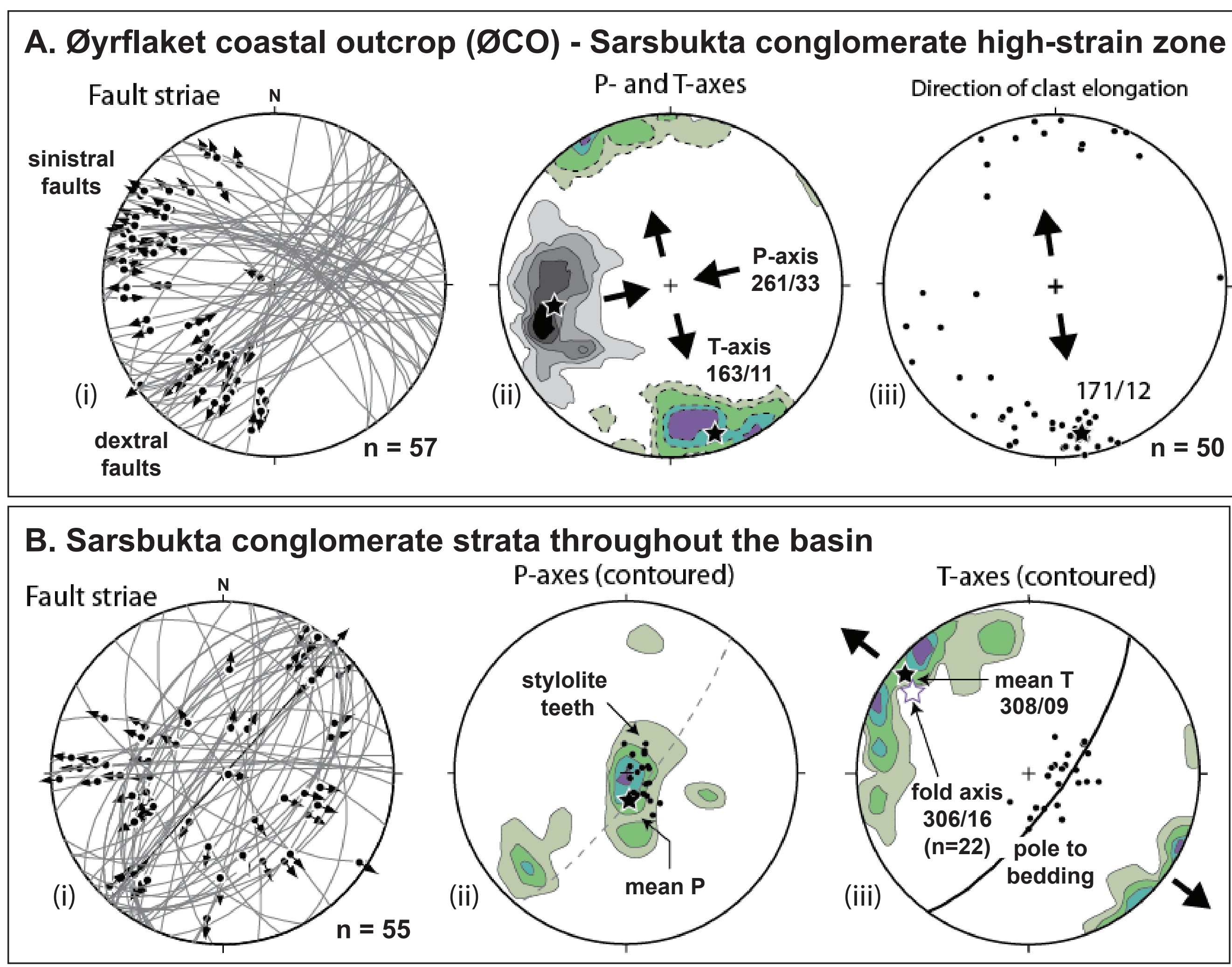

- Poles to stylolites $(n=73)$

$\square$ Poles to clast fractures $(n=61)$
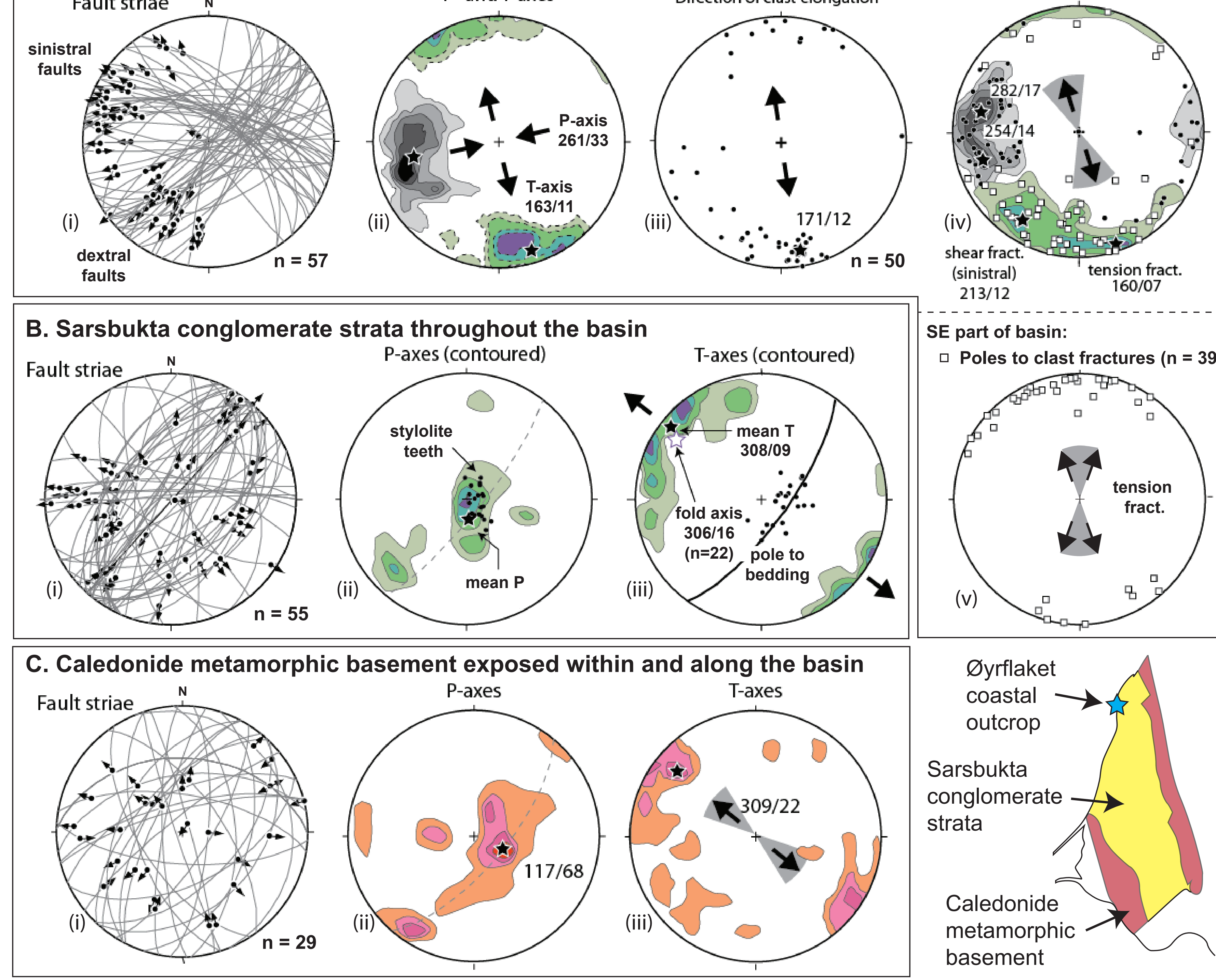

SE part of basin:

$\square$ Poles to clast fractures $(n=39)$
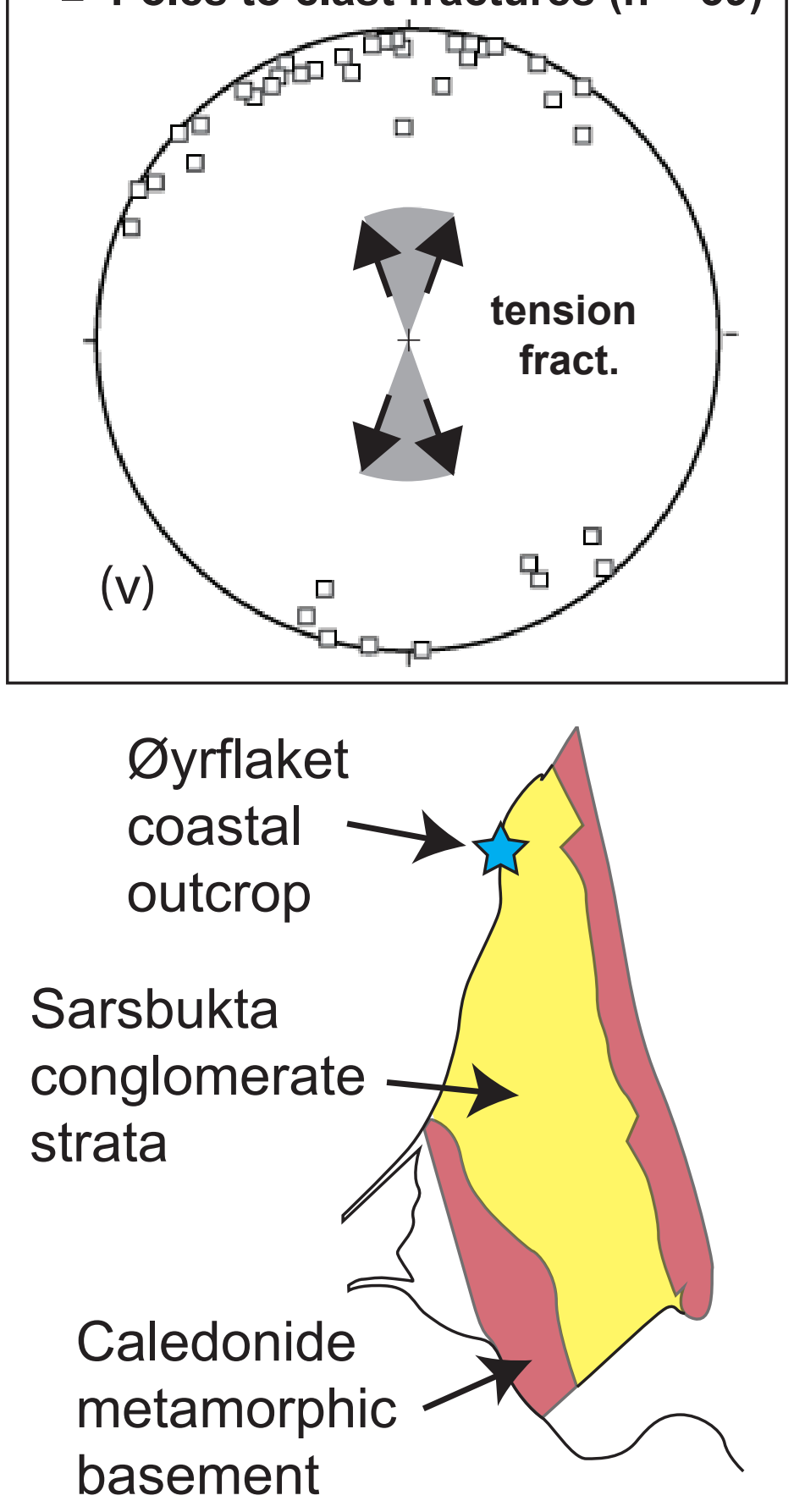

Fig. 7- Kleinspehn and Teyssier 


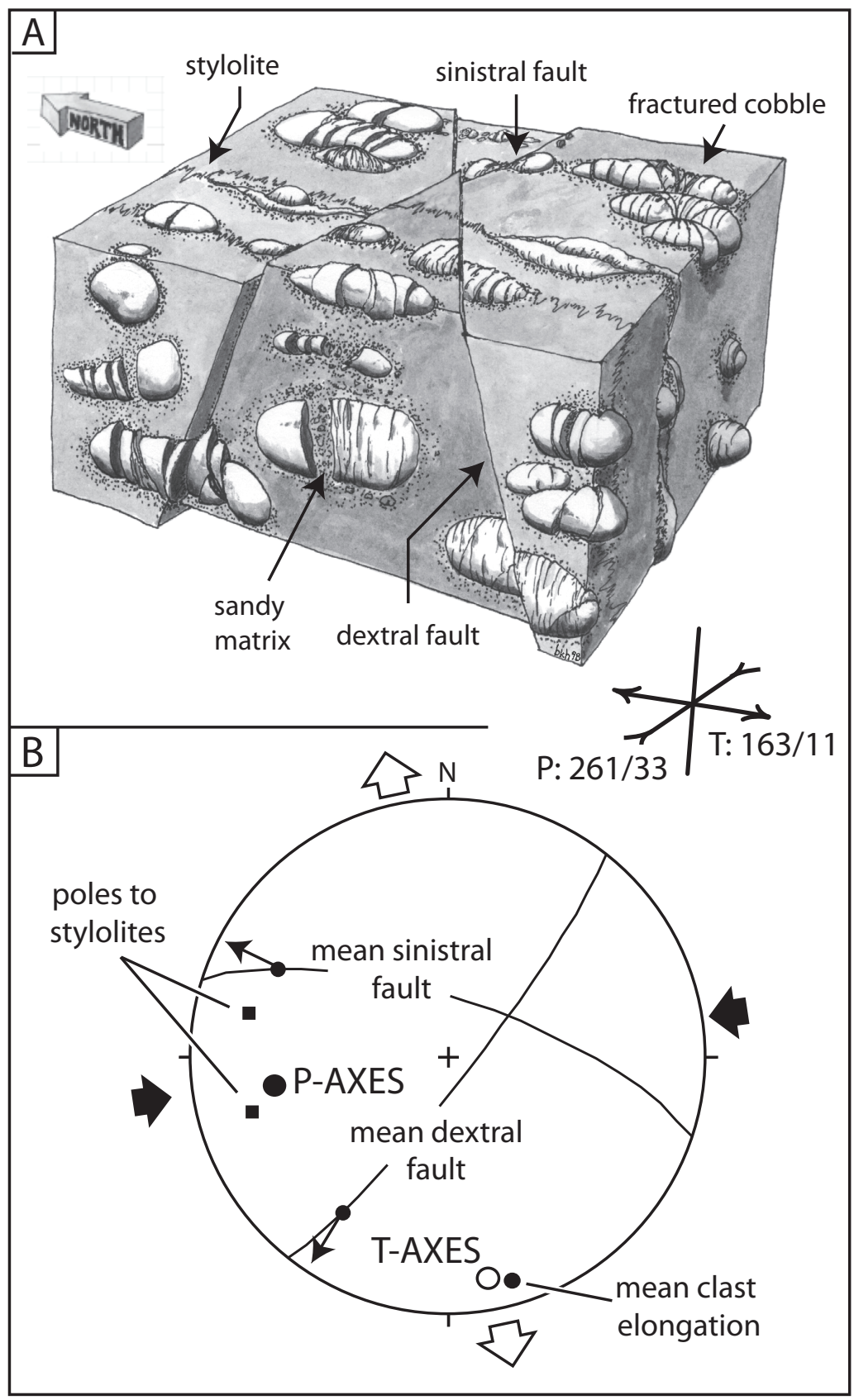

Fig. 8- Kleinspehn and Teyssier 


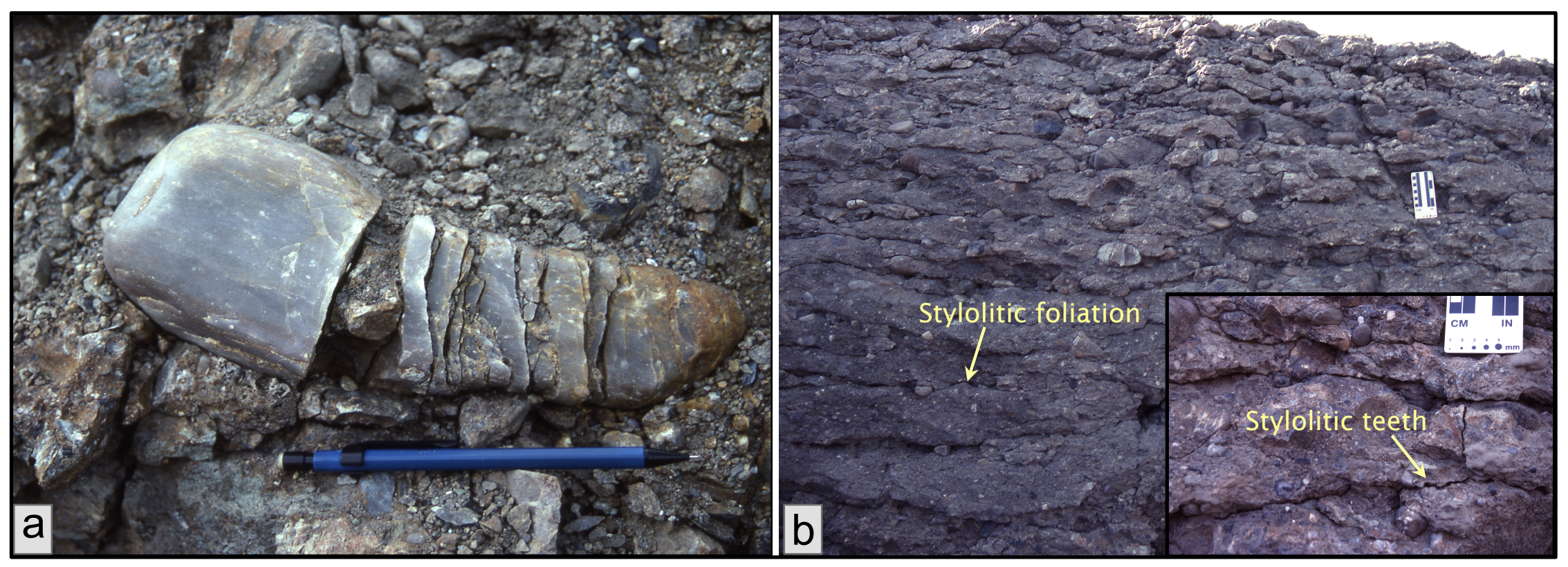

Fig. 9 - Kleinspehn and Teyssier 


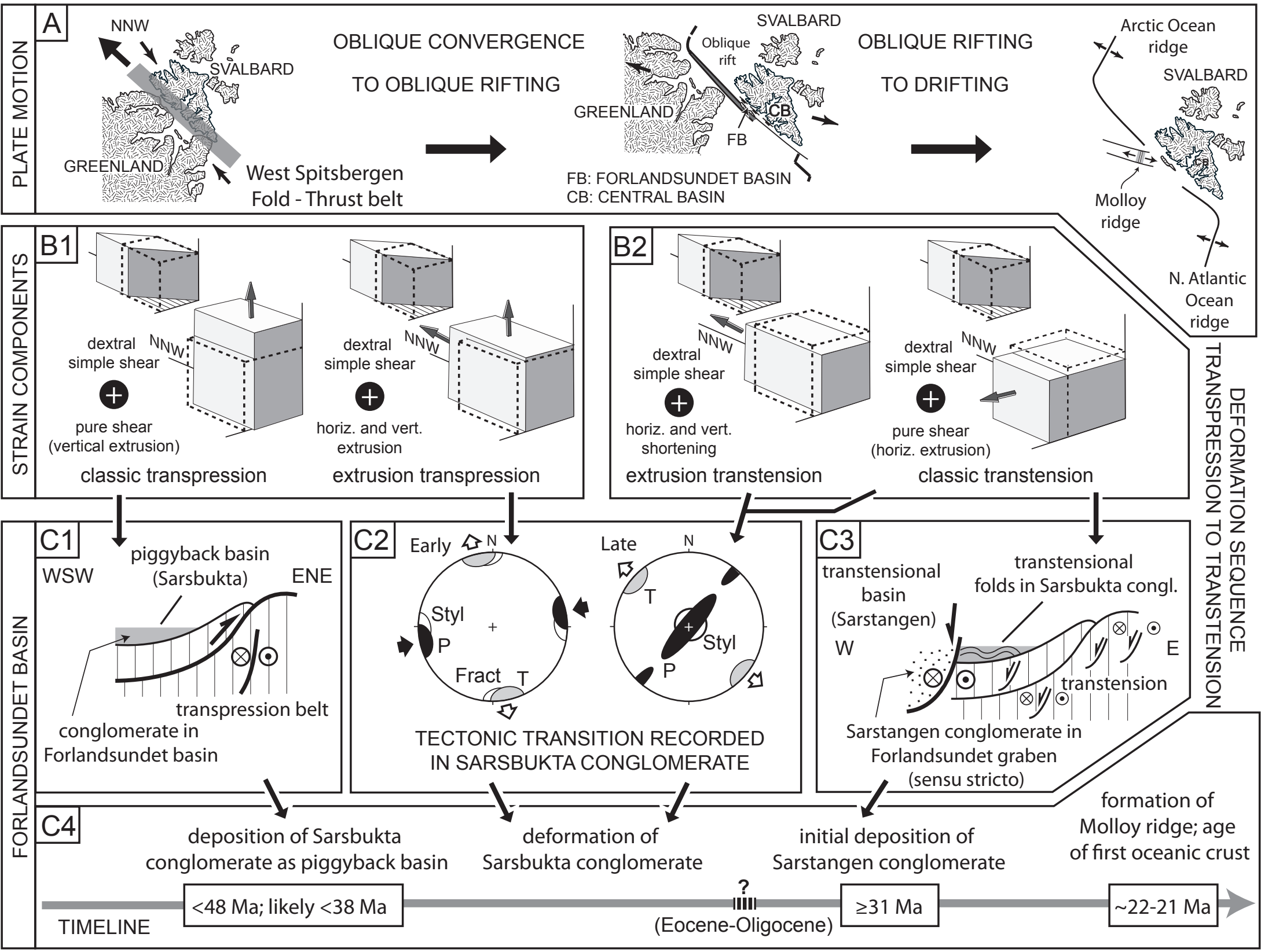

Fig. 10- Kleinspehn and Teyssier 

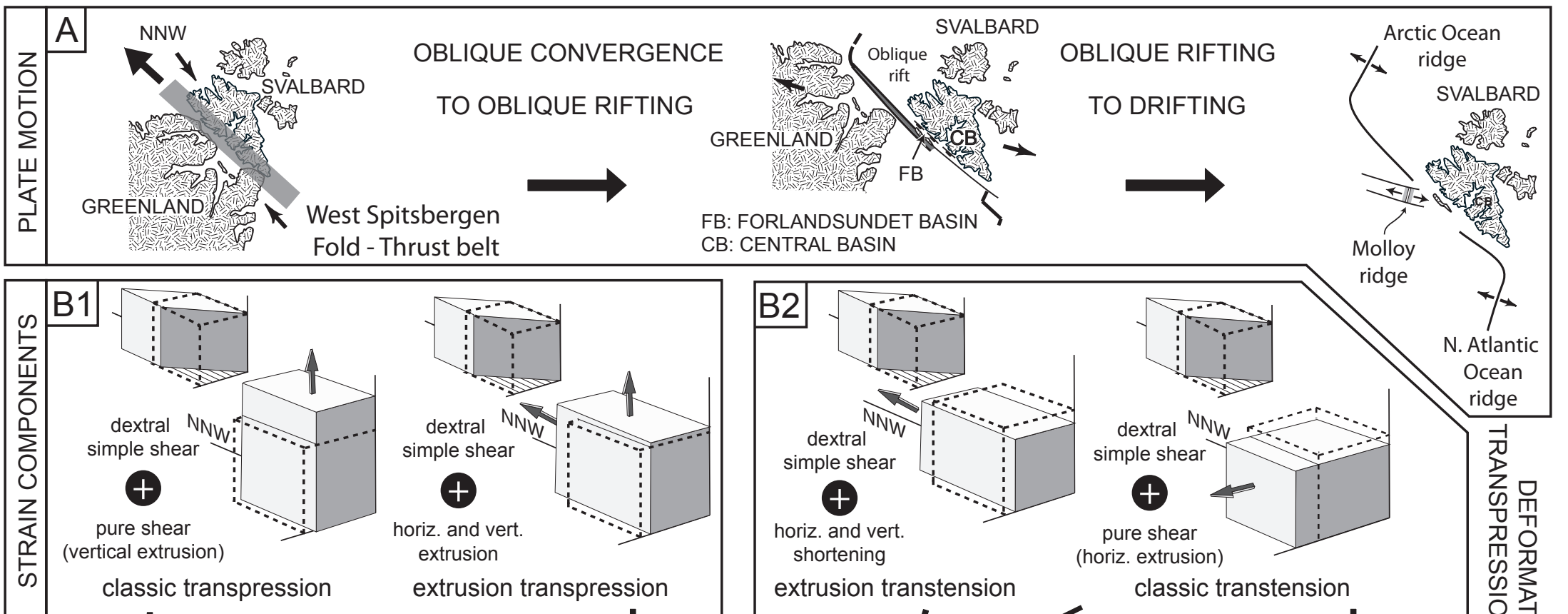

N. Atlantic

Ocean

extrusion transtension

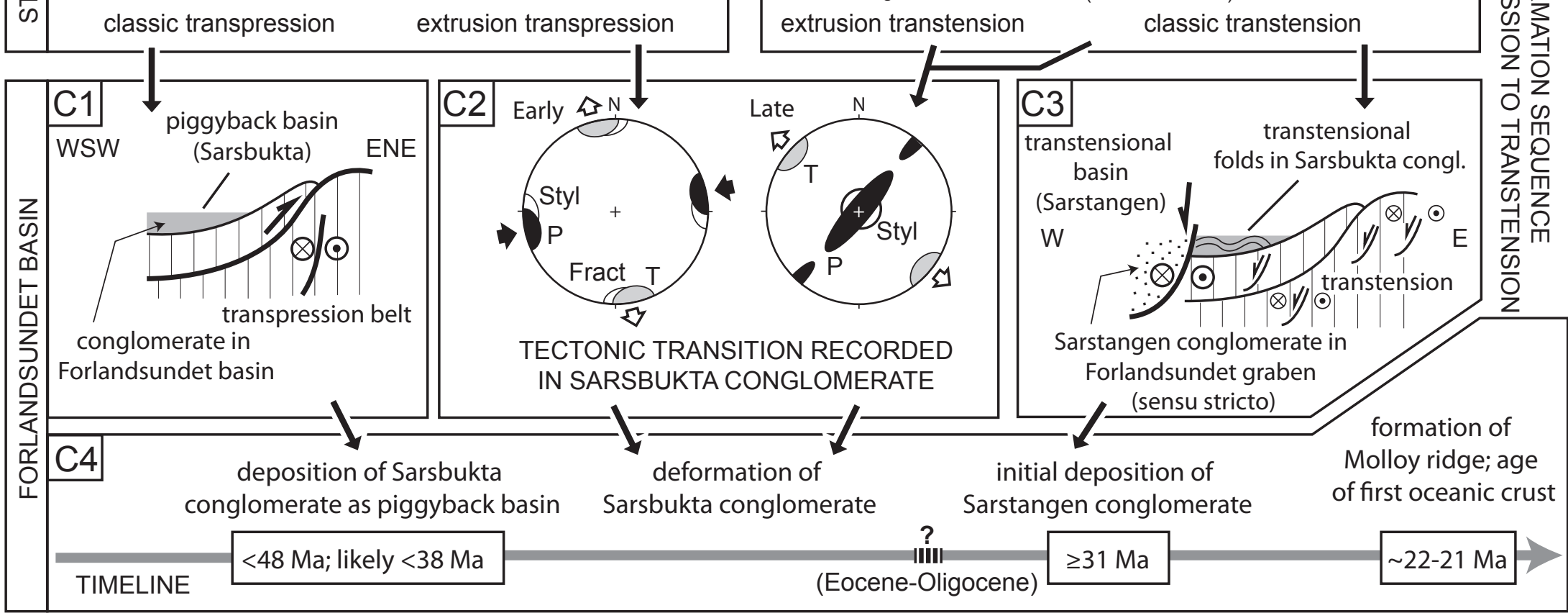

Fig. 10- Kleinspehn and Teyssier 